\title{
Iron triangles and subsidies: understanding the long-term role of the government on Swedish commercial fisheries
}

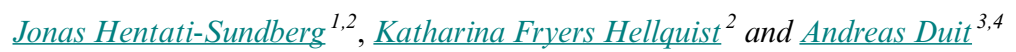

\begin{abstract}
Many natural resources have degraded and collapsed despite being managed under rigorous institutional frameworks set up to ensure rational exploitation. Path dependency of dysfunction institutions has been suggested as an explanation for such undesired outcomes. We explore the role of path dependency in natural resource management by studying a 100 -year evolution of Swedish fisheries. We rely on three main types of original longitudinal data collected for the period 1914-2016: (A) policy documents, (B) government spending on management and subsidies, and (C) catch and fleet data. Our analysis contrasts the periods before and after the Swedish entrance into the European Union (1995) because this marks the year when fisheries policy became beyond the direct influence of the Swedish government. We uncover four pieces of evidence suggesting the existence of a path dependent dynamic in the pre-EU period: (1) despite increasing insights on the vulnerability of fish stocks to overexploitation, national policy goals in relation to fisheries continuously promoted incompatible goals of social and economic growth but without any reference to the sustainability of the biological resources; (2) the same policy instruments were used over long periods; (3) actor constellations within the fisheries policy subsystem were stable over time; (4) neither political regime nor macroeconomic variables and fisheries performance (industry production, oil price, landing values) could explain observed temporal variation in subsidies. We conclude that key policy actors in the pre-EU period formed an "iron triangle" and thereby prevented necessary policy changes. These national reinforcing feedbacks have been weakened since EU entrance, and the indicators for path dependency show broader involvement of stakeholders, a shift in spending, and policy goals that now explicitly address ecological sustainability.
\end{abstract}

Key Words: fisheries; historical ecology; path dependence; resilience; social-ecological systems; subsidies; sustainability

\section{INTRODUCTION}

In the scientific discussion on sustainable use of natural resources, there is a classic divide between proponents of state control or privatization (Hardin 1968) and those emphasizing actors' selforganizational capacities in solving common property problems (Ostrom 1990, 2009). Both these strains of literature have an important thing in common: a tendency to disregard the fact that most natural resources and ecosystems are today governed by political and administrative institutions rather than by selforganizing users. Although it is true that collective action problems underlie many cases of natural resources overexploitation, overlooking the pivotal role of state actors and agencies often generates an incomplete model of real-world social-ecological systems (Finley 2011, Duit 2014, Stoll et al. 2016).

Many fisheries share the typical properties of overexploited natural resource systems. Although many fish stocks have recovered in recent years (Lotze et al. 2011, Ricard et al. 2012, Costello et al. 2016), overexploitation has been persistent and many stocks still suffer from past and present management failures (Ricard et al. 2012, FAO 2016). The well-known collapse of cod stocks off the coast of Newfoundland is an empirical example of how dynamics between state actors and the fishing industry can play out in collective action situations. These cod stocks had sustained an unregulated international fishery for centuries but collapsed within 15 years from the introduction of the Canadian Exclusive Economic Zone. Subsequent research suggests that scientific optimism on the stock growth potential and expansive national fleet policies played a key role in the collapse (Walters and Maguire 1996, Mason 2002). National policies have often catalyzed fishing fleet development with a goal to increase national shares of catches (Borgström 1966, Pauly 2006, Finley 2011, Österblom and Folke 2015). As of today the fishing industry remains heavily subsidized by national governments and overexploitation persists, leading to declining global catches (Watson et al. 2013, Pauly and Zeller 2016, Sumaila et al. 2016).

We suggest that the role of formal government institutions has been underestimated in the study of sustainability in fisheries and other resource systems, which motivated us to perform an empirical long-term analysis of policy making in this context. Specifically, we employ path dependency (PD) theory to analyze the evolution of Swedish fisheries (1914-2016). Although there are many different types of policy process dynamics with relevance for understanding natural resource management (see Orach and Schlüter 2016 for an overview), we focus specifically on one such policy-making dynamic: path dependency. We have chosen PD theory for three reasons. First, previous studies have argued that $\mathrm{PD}$ is a common phenomenon in most institutional settings (Pierson 2003, Duit 2007) and should therefore be of general relevance for the study of resource management institutions. Second, from a sustainability perspective, PD theory can generate more refined insights into the complex processes generating suboptimal management outcomes within formal, hierarchical, and politically controlled management institutions. Third, the idea of path dependent institutions resonates with theory building on resilience of social-ecological systems (SES), which has suggested that reinforcing feedbacks and "traps" can explain undesired trajectories in social-ecological systems (e.g., Nyström et al. 2012, Boonstra and de Boer 2014).

\footnotetext{
${ }^{1}$ Swedish University of Agricultural Sciences, Department of Aquatic Resources, Lysekil, Sweden, ${ }^{2}$ Stockholm Resilience Centre, Stockholm University, Stockholm, Sweden, ${ }^{3}$ Department of Political Science, Stockholm University, Stockholm, Sweden, ${ }^{4}$ Political Science Unit, Luleå University of Technology, Luleå, Sweden
} 
Our paper contributes to the available literature in three main respects. First, we compile and analyze a unique longitudinal qualitative and quantitative dataset of policy documents, policy actors, fishery subsidies, fleet size, and catches. Second, we develop a framework for systematically analyzing path dependency in SES. Third, we demonstrate that SES analyses should to a greater extent consider the role and dynamic of government institutions in managing natural resources.

\section{STUDY FRAMEWORK}

Research within policy studies, public administration, historical institutionalism, and institutional economics have argued that PD is a common phenomenon encountered in most forms of public governance. The idea is that most institutions and regulations are, in principle, path dependent to a certain degree (Arthur 1994, Kay 2003, Pierson 2003). Path dependency can explain why institutions, and thereby policy making, seem to be stable over time in the sense that drastic and significant changes in policy outputs and institutional configuration occurs very rarely (Jones et al. 1998, Pierson 2000). It also offers an explanation for why even severely dysfunctional or inefficient institutions can persist over long periods of time (Arthur 1994, Pierson 2003). PD within public administration and policy studies has several different definitions (Kay 2003), but the most widely accepted form defines $\mathrm{PD}$ as a self-reinforcing process driven by increasing marginal returns, i.e., that the value of an institution (a set of rules) increases over time for its users (Arthur 1994, Pierson 2003). A classic example is the QWERTY key board, which despite being an inefficient design for typing speed, has nevertheless remained the dominant design for keyboards worldwide. Pierson (2003) has argued that political institutions display similar features: they are often inefficient, remarkably stable, and sensitive to initial conditions in the historical trajectory.

The notion of path dependency can be linked to theoretical models in the SES tradition (Boonstra and de Boer 2014). Resource management studies have frequently shown that ecosystems are difficult to change back after collapses (Scheffer et al. 2001, Folke et al. 2004, Scheffer 2009). Complex systems research refers to this feature as state-dependence (Sugihara et al. 2012, Levin et al. 2013). State-dependence and path dependency are similar by noting the "stickiness" of complex systems; SES literature includes a number of specific mechanisms, termed reinforcing feedbacks, that promote such stability (Nyström et al. 2012).

Critics of path dependency theory have argued that many empirical applications tend to be theory-driven and consisting in just-so stories that cannot be falsified by empirical data (Pierson 2000, Kay 2003, Duit 2007). It is therefore important to design studies so that the absence of path dependency has an equal chance of finding support in the data. This has been the main analytical strategy for the study design of this paper.

We translated PD theory into four hypotheses. Our first two hypotheses centered on policy goals and policy instruments selected and employed by government actors throughout the history of the policy subsystem. We assume that PD, if present, will be manifested in significant stability in policy goals and increases in investments in the main policy instruments. Policy instruments are operationalized as the total government spending on fisheries, which has been organized as a number of subsidy programs. Stable policy goals and instruments and increasing investments are considered a sign of increasing returns to the institutional framework, whereas shifting goals, changing policy instruments, and varying levels of investments in the policy instruments all would indicate absence of a PD process. We hypothesized that,

H1: Policy goals will exhibit a high degree of internal stability and consistency over time.

$\mathrm{H} 2$ : Investments in main policy instruments (subsidies) will increase over time.

Stability in policy objectives and choice of policy instrument are important indicators of path dependency in a policy-making institution, but the absence of change does not necessarily imply PD at play. A well-established finding within policy studies is that most policy subsystems are based on a coalition of actors who agree on problems, goals, and instruments (Sabatier 1999). The stability of the policy coalition is thus essential for stability of the policy subsystem and we assume that changes, i.e., actors leaving or entering the institution, in the set of actors active within the institutional structure would indicate an absence of a PD trajectory. Our hypothesis was,

\section{H3: Actor constellations will be constant over time.}

Finally, we were interested in the robustness of the PD process to external shocks and disturbances. If genuinely path dependent, the primary driver of the historical trajectory should be itself, which means that external events will not have a systematic relationship with the state of the path dependent institution. Consequently, our last hypothesis was,

H4: Policy instruments will be resistant to exogenous shocks.

\section{METHODS AND DATA}

Our four hypotheses were tested for the period from the onset of national fisheries policy in the early 20 th century until Sweden entered the European Union (1995). We also analyzed data for 1995 onward to investigate whether any change could be detected after the EU entrance.

To test H1, stable policy goals, we backtracked official policy goals throughout the study period. We relied on Swedish Government Official Reports ("Statens Offentliga Utredningar," SOU), reports by committees appointed by the government on issues in anticipation of a proposed legislation. All major policy changes and legislation in Sweden are supposed to be preceded by a government oversight committee consisting of experts and representatives for organized interests within the policy area. The committee conducts investigations and makes recommendations for policy in the form of a committee report delivered to the relevant minister. This system is a cornerstone in Sweden's social corporatist governance system designed to allow for the key national interests to reach agreements and solve conflicts before, rather than after, the implementation of a policy (Lewin and Lindvall 2015). These reports were used because they provide a rich background to the perceived reform needs as well as a summary of the goals of the current policy at the time of the report. We performed an in-depth qualitative analysis of all reports relating to Swedish fisheries published during the study period $(n=9$, temporal scope 1922-2010). 
To test $\mathrm{H} 2$, increase in spending over time, we relied on the Swedish government budget (1914-2016), and for the period since Swedish entrance into the EU in 1995, also data from the EU Commission (1995-2016; Appendix 1). Following Sumaila et al. (2010), all spending was categorized into a number of subcategories, sorted under three main categories: beneficial, capacity-enhancing, and ambiguous. These three categories were defined in relation to their expected effect on fishing sustainability, whereby the beneficial category includes research and management; the capacityenhancing includes direct industry support, i.e., fuel subsidies, ship-building support, port construction, marketing support, and fishery development projects; and the ambiguous category includes industry support that has effects that are difficult to evaluate in terms of sustainability, such as financing the unemployment fund for fishermen and vessel scrapping subsidies. Detailed motivations and descriptions of the different subsidy categories are given in Table A1.1. A list of all types of governmental spending on fisheries observed during the study period and how we categorized them is given in Tables A1.2 and A1.3. Our analysis focuses on commercial sea fisheries, and we therefore excluded support to commercial freshwater fisheries, recreational fisheries, and aquaculture. Generally, the budget proposals explained succinctly the purpose of a specific spending program, which allowed us to directly assign them to the relevant category. In some cases, where the purpose was less clear from the budget proposal, we traced the specific program back to the legal text, published in the form of Royal Decrees (1892-1993) and Statutes of the Swedish Board of Fisheries (1985-2010). Both these are legally binding regulations and announcements. We controlled annual spending for inflation using the Swedish Consumer Price Index (CPI; Statistics Sweden 2019); all values in the paper are expressed in fixed prices (Swedish Krona in year 2011 values, $10 \mathrm{SEK} \approx 1.1 €$ ).

Data to test H3 was derived from Swedish Government Official Reports (described above). Each report lists all individuals that acted as committee members, along with organizational affiliations. Hence, we could identify key organized interest in the fishery policy sector and tracked the distribution of these actor constellations over time.

To test $\mathrm{H} 4$ we analyzed statistically whether political regime and macroeconomic variables could explain interannual changes in spending, using General Linear Models. We used models with two different dependent variables: (1) the total amount of governmental spending on fisheries, and (2) the ratio of beneficial to capacity-enhancing subsidies. As independent variables we used manufacturing industry production, political regime in the Swedish government (categorical variable), oil price, landing value of the total Swedish fishery, year and 1-5 y time lags of the dependent variable to handle temporal autocorrelation. The motivation for those variables was the following. Manufacturing industry production was used to capture the general economic activity of the country (business cycle) because fisheries-related spending could be expected to follow the general economic activity of the country. We did not use GDP because fishing would to a small degree be reflected in the GDP figure, creating a dependency in the data. Swedish political regime was used to seek out a political difference in the government's spending. We used three categories based on the political history of Sweden: (i) social-democratic, (ii) liberal/conservative, and (iii) mixed/ technocratic. Oil prices were used because they have been shown earlier to strongly affect the economy of fishing fleets (Cheilari et al. 2013) and thereby could be hypothesized to drive increased subsidies. Landing value was used to search for a possible intrinsic system feedback from fisheries performance to subsidy spending. Year was used to account for a long-term trend in the spending that could not be explained by the above-described variables but any other type of long-term change, for example, relating to increasing knowledge or technological development. For the statistical analysis we used an information theoretic approach where we fitted models with all combinations of variables and calculated model weights and average parameter values based on Akaike Information Criterion (AIC; Burnham et al. 2011). With the relatively long final time-series data set (1915-1994, 80 years) we believe that any signal from the economic and/or political side on subsidies would be detected using this approach.

In order to assess the effect of subsidies on the fishing industry and fishing sustainability, we collected data on number of fishing vessels and their engine power from official statistical yearbooks (1914-1995) and the current Swedish governmental fishing fleet database (1996-2014). From this, we calculated the annual fishing fleet size measured in $\mathrm{kW}$. We also collected data on landings for different species, which we summarized by year.

\section{RESULTS}

\section{Policy goals 1914-2014}

The goals of the Swedish fisheries policy from the early 20th century until the EU entrance shows a gradual development from no specified goal toward increasingly detailed and convoluted goal formulations (Table 1). In 1948, a central government agency, Swedish Board of Fisheries, was established as the first national institution to provide for the development of the Swedish fishing sector. This happened as a result of the 1945 fisheries investigation that was commissioned to investigate the possibilities of sector development in the post-WW2 era (Swedish Board of Fisheries 1998). The introduction of a central and coordinated responsibility, and the establishment of a central policy goal for fisheries defines the start of a national expansion phase of Swedish fisheries (Table 1).

In 1970, the goals were expanded and partly reformulated. We consider this a consolidation phase for the policy developed during the expansion era (Table 1). Fishing was now articulated as a sector with great importance for the Swedish society for employment, cheap nutrition, and general welfare. The consolidation of policy goals and the increased budget spending arose from a set of immediate intrinsic and extrinsic problems perceived to face the fishing sector, including fleet over-capacity, profitability problems, lack of demand of some heavily targeted species, collapse of North Sea herring, and international law development in which Sweden lost traditional fishing grounds in the NE Atlantic (SOU 1977).

Since 1995, Swedish fisheries policy is subsumed under the Common Fisheries Policy of the European Union. EU policy goals for fisheries (which were revised in 2002 and 2014) do consider social and economic aspects of the fishing sector, but are also explicitly referencing ecological sustainability, which contrasts with the national goals in the pre-EU period (Table 1). With $\mathrm{H} 1$ we hypothesized that policy goals would be stable over 
Table 1. Goals of the Swedish fisheries policy 1914-1995, and goals for the EU Common Fisheries Policy (CFP) added for reference. Original quotes in Swedish were translated by the article authors.

\begin{tabular}{|c|c|c|}
\hline Policy phase & Year & Summary \\
\hline $\begin{array}{l}\text { Early } \\
\text { Development }\end{array}$ & 1914-1946 & $\begin{array}{l}\text { No stated overarching goal, but a range of specific management measures aimed at stimulating, (i) fisheries } \\
\text { research (mainly finding new fishing waters and developing fishing gear), (ii) development of new fisheries } \\
\text { (including distant water fisheries), (iv) port construction and other fisheries infrastructure, and, (iv) improved } \\
\text { economic status of the fisheries sector through marketing support and various direct subsidies to the fishing } \\
\text { fleet (See also Table A1.1) }\end{array}$ \\
\hline Expansion & 1947-1969 & $\begin{array}{l}\text { The goal for the Swedish fisheries shall be [...] to maintain income levels approximately in level with agriculture. } \\
\text { [...] Based on the discouraging experiences of the development of the fishing sector in the period after the last war } \\
\text { [WW1], the investigation is concerned that a relatively extensive subsidy program will be needed in order to } \\
\text { maintain profits at such levels. [...] The investigation will however stress that such support cannot be considered } \\
\text { desirable, but must be a last resort if profitability cannot be otherwise maintained at a satisfying level. (SOU } \\
\text { 1947:246) }\end{array}$ \\
\hline Consolidation & 1970-1994 & $\begin{array}{l}\text { [As decided by the Swedish government in 1970,] the goal for the fisheries policy should be to use market and } \\
\text { structural political measures to create stable economic conditions for a fishery that is well adapted to domestic } \\
\text { sales and for export. Conditions within Sweden shall be stabilized through price regulation mechanisms. } \\
\text { Rationalization shall be supported through structural political grants. The basis for the activities shall be to seize } \\
\text { the conditions for productivity within the Swedish fishing sector at the same time as the production capacity is kept } \\
\text { within the limits set by marketing in a longer time frame. (SOU 1977:127) }\end{array}$ \\
\hline
\end{tabular}

The basis for the Swedish fisheries policy is to exploit water and fish resources in such a way that it can contribute to food supply and general welfare [...] The goal for fisheries politics is to create conditions for social standard and work security for those working in the fishing sector that is comparable to the other industries, while consumers are offered fish of good quality for reasonable prices. Within the limits set by responsible use of the fish supplies shall fishing be conducted as efficient as possible and the level of catches be determined by the opportunities for profitable and stable production. At the same time shall regional political needs for employment in coastal and archipelagic regions be taken into consideration. (Swedish Board of Fisheries 1986:2)

EC-1 1995-2001 [...] the objective should be to provide for rational and responsible exploitation of living aquatic resources and of aquaculture, while recognizing the interest of the fisheries sector in its long-term development and its economic and social conditions and the interest of consumers taking into account the biological constraints with due respect for the marine ecosystem. (EC 1992:1)

EC-2 2002-2012 The objective [...] should therefore be to provide for sustainable exploitation of living aquatic resources and of aquaculture in the context of sustainable development, taking account of the environmental, economic and social aspects in a balanced manner. (EC 2002:1)

2013-present The CFP should ensure that fishing and aquaculture activities contribute to long-term environmental, economic, and social sustainability [...] Furthermore, the CFP should contribute to increased productivity, to a fair standard of living for the fisheries sector including small-scale fisheries, and to stable markets, and it should ensure the availability of food supplies and that they reach consumers at reasonable prices. The CFP should contribute to the Europe 2020 Strategy for smart, sustainable and inclusive growth, and should help to achieve the objectives set out therein. (EC 2013:art. 4)

time, while our empirical analysis reveals that the pre-EU period did show a gradual evolution toward more complexity yet ignoring ecological sustainability, whereas the EU entrance led to a clear shift, specifically by referencing ecological sustainability.

\section{Policy instruments: subsidies 1914-2014}

Governmental spending on fisheries has been organized as a set of different programs with varying temporal scope (Tables A1.2 and A1.3). Research and management spending have increased continuously over our study period and were in the end of the study period on the highest level recorded (Figs. 1 and 2A). Capacity-enhancing subsidies were initially low, but increased gradually until a peak in the 1980s, and declined thereafter (Figs. 1 and 2B). In the early 1900s, the dominating spending was on port construction, i.e., basic infrastructure, vessel construction, and fisheries development projects. Later, during the most heavily subsidized period in the 1960 s to 1980 s, vessel construction dominated the spending, but fishery development projects also remained important. In recent years, all historical subsidy types remain, but the dominating spending has been on marketing and storage infrastructure. Diesel has remained subsidized throughout the study period but is invisible in the governmental budgets because the subsidy is arranged as a fuel tax exemption (SFS 1994). Ambiguous subsidies, i.e., support that could either lead to fleet increase or fleet reduction depending on the specific circumstances (Table A1.1), have existed since the 1930s, and increased after year 2000, mainly resulting from a series of buyback programs funded by the EU and Sweden (Fig. 1 and 2C).

In total, the governmental spending over the century-long period was 6.2 (beneficial), 5.0 (capacity-enhancing), and 1.0 (ambiguous) billion SEK. The total spending is currently the highest level recorded, $291 \mathrm{M} \mathrm{SEK}$ as an average for 2013-2015.

The fishing fleet trend over time includes two broad phases; an initial increase followed by a later decline (Fig. 3). The earlier peak in number of fishing vessels (Fig. 3A) compared to the aggregated engine capacity of the fleet (Fig. 3B) reflects the strong technological development during the study period, i.e., the average vessel has become larger. The increase in fishing capacity from 1945 to the peak year 1988 was $297 \%$, and from 1914 to 1988 over $800 \%$. 
Fig. 1. Availability of different categories of subsidies over time. Green color denotes beneficial subsidies, red capacity-enhancing, and yellow ambiguous subsidies. For full description see Table A1.1. M SEK = millions, Swedish Krona.

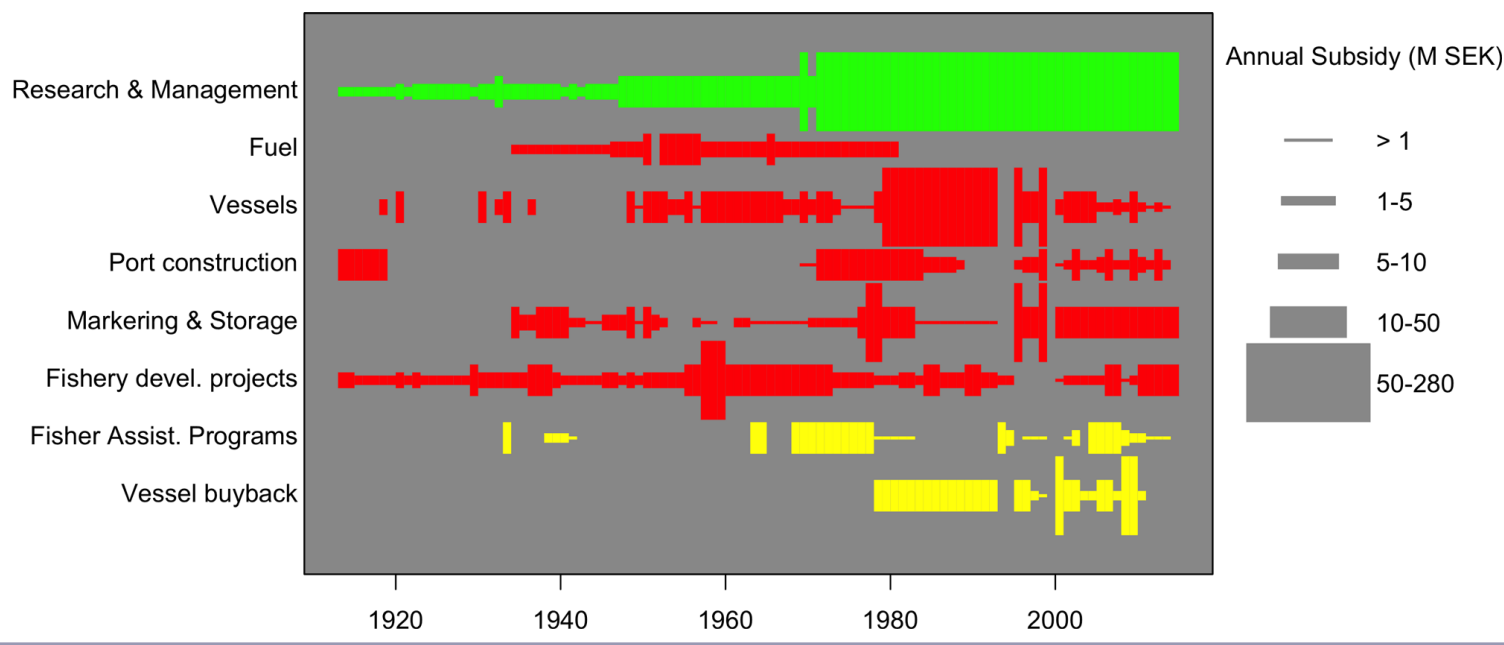

Fig. 2. Change in governmental spending on fisheries (A: beneficial, B: capacity-enhancing subsidies, and C: ambiguous) toward fisheries (1914-2015). M SEK = millions, Swedish Krona.

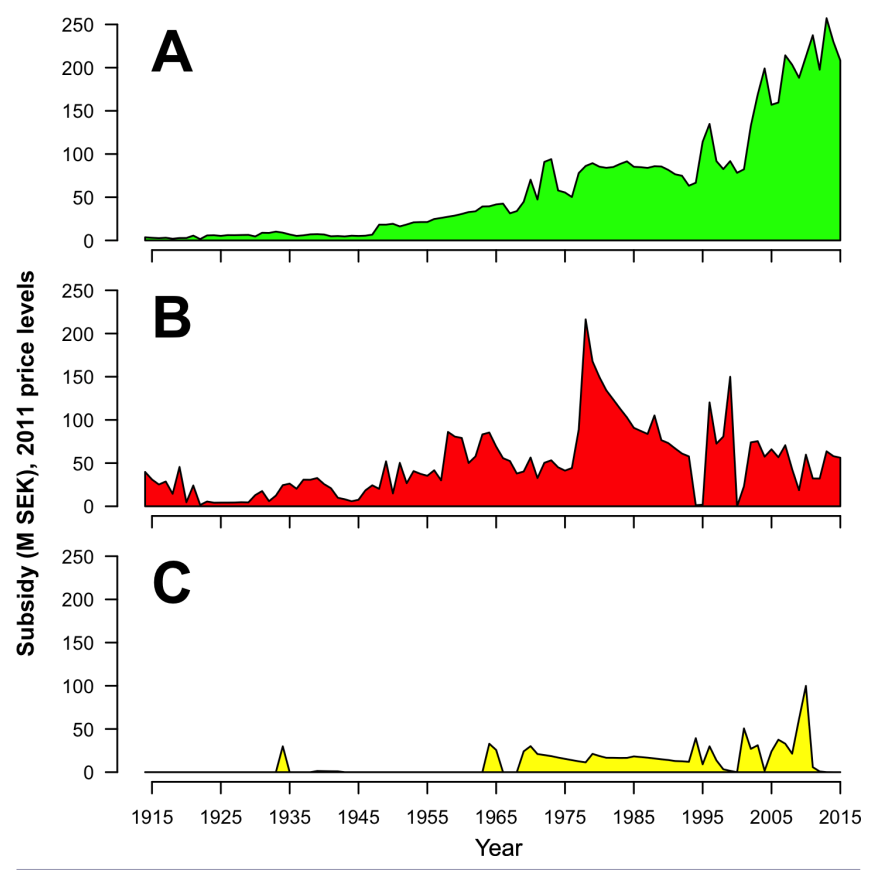

Economic theory suggests that capacity-enhancing subsidies have a direct effect on reducing the cost of fishing and will thereby stimulate investments in the fleet and increase fishing effort (Sumaila et al. 2010). However, one could also argue for a reverse causality: that a large fishing fleet requires high subsidies to remain profitable. It is clear that the general trend in fishing fleet size measured as engine size (Fig. 3B) coincides with capacity
Fig. 3. Size of the Swedish fishing fleet 1914-2014. (A) Number of vessels, which is roughly proportional to the number of commercial fishers. (B) Sum of engine power $(1000 \mathrm{~kW})$. Fleet subsidies have also supported effort-increasing technologies that are not reflected in our measure of the fleet, such as improved gear, sonar (fish finding) technology, navigation, and onboard facilities such as freezing technology, which suggests that our way of measuring fishing capacity is conservative.
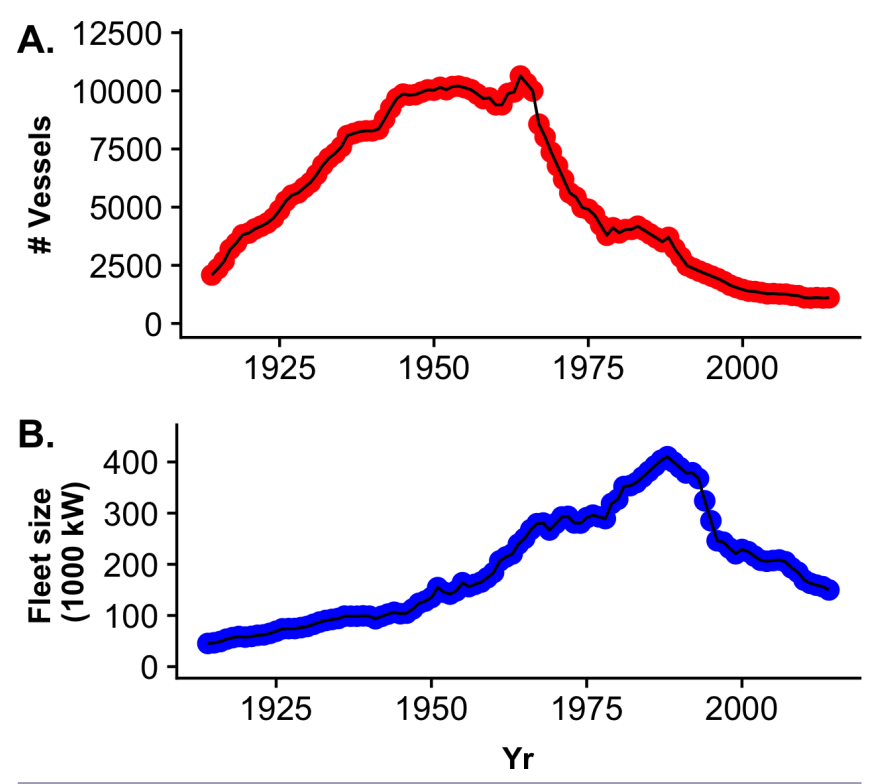

enhancing subsidies (cf. Fig. 2B). To further investigate the two contrasting hypotheses on "what drives what," we analyzed the correlation between subsidies on fishing fleet size using temporal lags spanning between -19 and 19 years. We found that earlier years' subsidies best explained present fleet development, with a peak in prediction power of four years between subsidies and 
fishing fleet size (Fig. 4). This finding is well in line with how subsidy programs can be expected to affect fishing fleet development: first of all, there is a time lag between a decision to construct a new fishing vessel until the vessel is operational; second, subsidies for vessel construction were dominantly transferred via a capital fund run by the government, which in turn supported individual vessel construction and modernization projects. Thus, a four-year lag between governmental spending until a vessel is operational is reasonable given how the system was organized.

Fig. 4. Temporal lags in capacity-enhancing subsidies and their effect on fishing fleet development. (A) Left panel shows $\mathrm{R}^{2}$ for linear models having fleet size (Fig. 3B) as dependent variable, and capacity enhancing subsidies (Fig. 2, middle panel) as independent variable. The dotted line shows lag $=0$, i.e., instantaneous response of the dependent variable on change of the independent variable. The peak in correlation occurs as -4 yr lag. (B) The two time-series, plotted with a -4 yr time lag. Grey circles denote the actual subsidies in a given year and the black line denotes a 5-year moving average of the subsidy level. The red line denotes the fleet size measured in $1000 \mathrm{~kW}$. M SEK $=$ millions, Swedish Krona.
A.

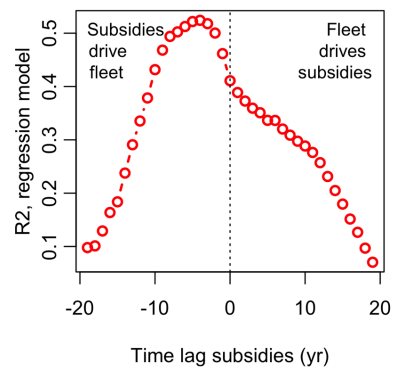

B.

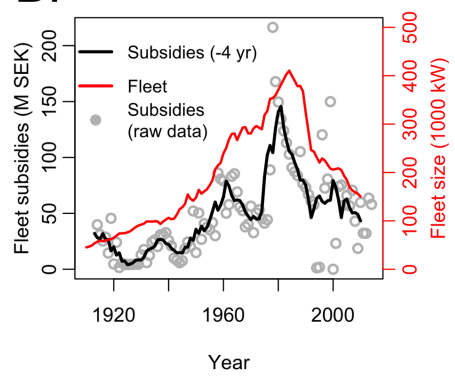

Landing quantities in Swedish fisheries has over time been driven by a few species, notably herring and forage fish (Fig 5A). Landing values are more evenly distributed between many species (Fig. 5B). The dramatic increase in fishing capacity during the 20th century has not been reflected in comparable landing increases; in fact landings declined remarkably during the end of consolidation phase 1965-1990 at the same time as effort and capacity-enhancing subsidies reached their all-time high (cf. Figs 2B, 3B, and 5A).

Our hypothesis $\mathrm{H} 2$ was that path dependency would lead to increasing investments in the main policy instruments over time. Our data show that all the main policy instruments that existed in the middle of the 20th century were still in operation toward the early 1990s (including diesel that remains an invisible subsidy), leaving the total program of governmental spending related to the fishing sector intact in the period from WW2 until the late 20th century despite the fact that the magnitude of investments have varied on annual and decadal scales (Fig. 1). However, since year 2000, we see a possible acceleration of an already ongoing trend where capacity enhancing subsidies has declined while management and research has increased dramatically. This gradual greening of the policy is ongoing. At the same time, it must be noted that the total governmental (Swedish and EU) spending on fisheries is on the highest level recorded (Fig. 2), at the same time as the number of fishers have declined, which has led to a dramatically increased management cost per active fisher (Fig. A1.1) as well as increased subsidies as a fraction of landing value (Fig. A1.2).

Fig. 5. Landings in the Swedish sea fishery 1914-2015. (A) Landing quantities. Note that the trend is mainly driven by two groups, herring (Clupea harengus) and forage fish, which in turn consists of a few different species used for reduction to fish meal and fish oil, mainly sprat (Sprattus sprattus), blue whiting (Micromesistius poutassou), sand eel (Ammodytes sp.), and herring. (B) Landing value. Note the more even distribution between groups, and the relatively large share of "other species" and that total landing value peaked as early as 1963 despite the subsequent strong increase in fishing power. Other species mentioned in the figure are Atlantic cod (Gadus morhua), Atlantic mackerel (Scomber scombrus), and Northern prawn (Pandalus borealis).
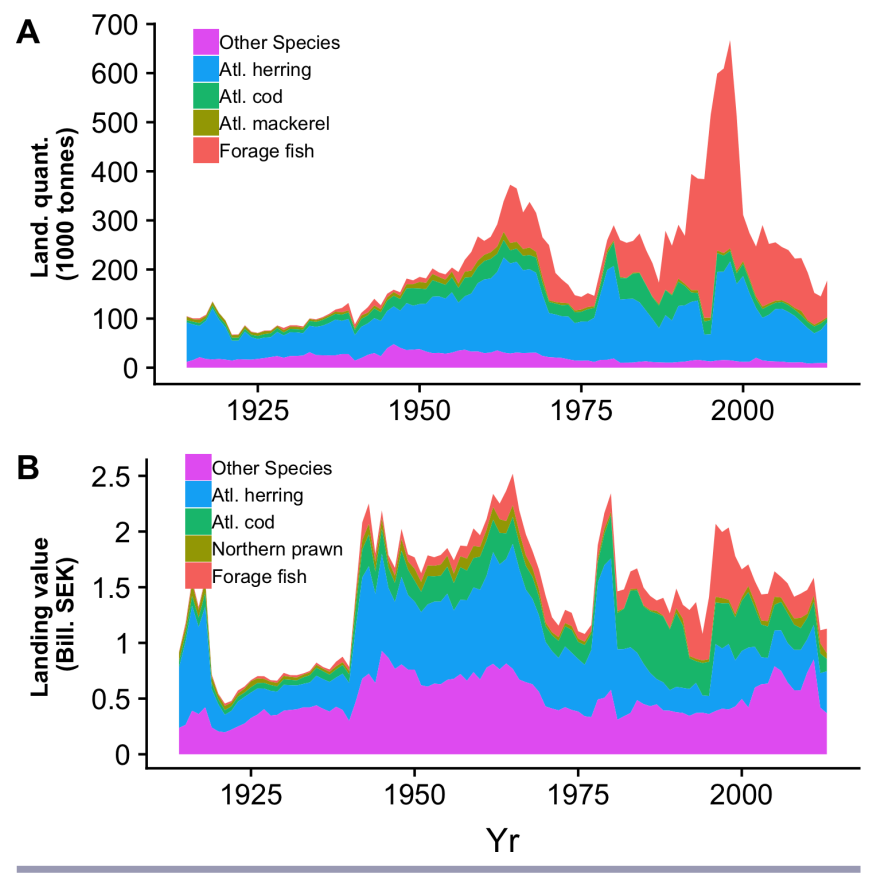

Policy actors 1922-2010

The fishing industry has had the highest representation in the government committees commissioned to propose fisheries reform in the period 1992-2010 (Fig. 6). The other two groups that have been consistently represented in the committees are the fisheries management agency and the Ministry of Agriculture (Fig. 6). However, year 2010 stands out as other actors have had a significant (42\%) representation (mean 1922-1992: 10\%, range: $0-25 \%$; Fig. 6). Those actors included, e.g., NGOs for the environment, recreational fisheries, and people in coastal and archipelagic regions, and several ministries, including the Ministry of the Environment and the Ministry of Defense. Despite the fact that the original three actors together had $58 \%$ of the representation, it illustrates that it has been possible for stakeholder groups other than commercial fishermen to influence policy in recent years. In summary, we find that actor 
constellations have been relatively intact between 1922 and 1992, giving support to hypothesis H3. Because the government committees are conceived to include all relevant interests in the formulation of a new policy, the lack of "other" actors in this long period signals a concentration of power in a small group, as further evidenced by the sudden shift observed in 2010. The "new" actors represented in the 2010 committee existed also in the earlier periods, indicating a true shift in the representation and not only in the availability of stakeholders.

Fig. 6. Representation in the Committees presenting the Swedish Government Official Reports in the period 1922-2010. The committees for the years 1937, 1970, and 1989 were not included because of the few members and the limited scope of the assignment to those committees. For 1922 and 1951, there were a few members for which we have not found any biographical information that could be used to categorize them.

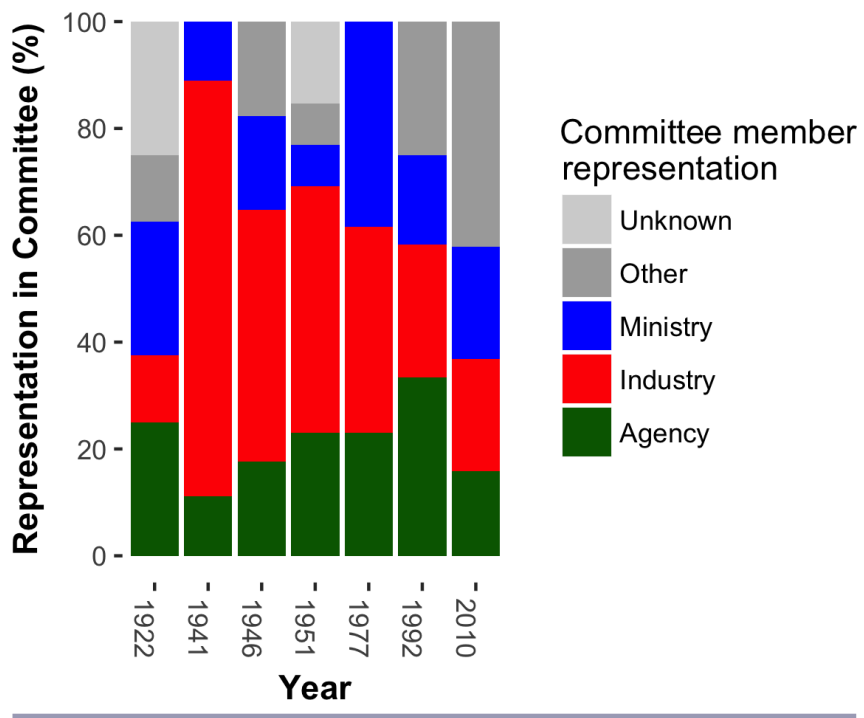

Resistance to shocks in subsidy spending

The final step of our analytical strategy was to test quantitatively whether macroeconomic data, political regimes, or general system performance could explain the change in subsidies over time. We tested two dependent variables, total spending and subsidy color (fraction negative to positive subsidies), and found that neither political, macroeconomic factors (including oil price), nor system fisheries performance (landing value) could explain any of the variation in these variables (Fig. 7, Tables A1.4-A1.7). In both sets of models, the data for the year before was the only strong predictor (mean value of 1-year autocorrelation [AR1] 0.75 and 0.66 for total spending and subsidy color, respectively, Tables A1.6-A1.7), in itself an indication of path dependence. Autocorrelation on 2-5 years lag (AR2-5) did not contribute significantly to predicting subsidy color or total subsidy level.

\section{DISCUSSION}

Historical trajectory of Swedish commercial fisheries

Many commercial fisheries have collapsed despite strong governmental institutions, significant research efforts, and detailed management plans. Could an increased understanding of the historical institutional dynamics reveal drivers behind the suboptimal performance of fisheries and other natural resource systems? To investigate this, we applied path dependency theory in a long-term analysis of Swedish fisheries policy. We formulated four hypotheses about the existence of a path dependence in the period from the start of Swedish official fisheries policy (early 1900s) until the end of the 20th century. The first hypothesis (H1) stated that we expected stability over time in how policy goals were conceived by institutional actors, and the analysis of key policy documents from the period 1922-1994 showed that the dominating pattern was an evolution toward more complexity yet a notable avoidance of references to ecological sustainability. The second hypothesis $(\mathrm{H} 2)$ stated that investments in policy instruments would increase over time. Again, we found some support for the hypothesis in the data: total governmental spending displayed a steady increase over time while it must be noted that the type of subsidies has gradually changed toward more beneficial and less capacity-enhancing. The third hypothesis (H3) was about actor constellations, and we found that the set of actors active within the institutional framework remained more or less unchanged before the Swedish EU entrance with a high dominance of representatives from the fishing industry during the whole study period and very little involvement of other stakeholders. The fourth hypothesis (H4) was about the robustness of the path dependence trajectory, where we found that history (spending in the year before) was indeed the only factor we could link to subsidy spending and that macroeconomic, political, and fisheries performance (landing values) factors had no measurable effect.

Fig. 7. Independent variables used to investigate drivers behind changes in subsidies.

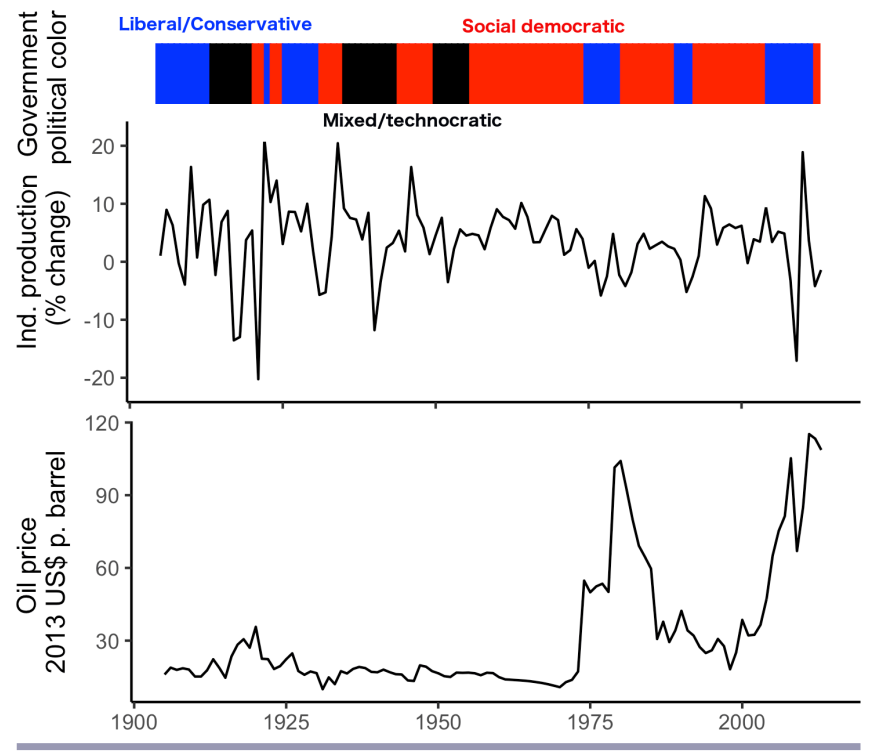

The Swedish EU entrance in 1995 changed a number of things. Policy goals have increasingly included references to ecological sustainability, notably through noting the limits to biological productivity (EC 1992), sustainable exploitation (EC 2002), and after the most recent reform through the goal of all stocks at the maximum sustainable yield level (EC 2013). Although the total 
spending on fisheries continues to increase, the "greening" trend that has been present during the whole study period seems to have accelerated since the EU entrance with a growing proportion of money on research and management and proportionally less on capacity-enhancing subsidies.

\section{Indicators of path dependency}

We defined policy instruments as the governmental spending on subsidies, monitoring, and control, which are indeed key instruments of the government in supporting fisheries, and which can illustrate the general direction of the policy (Sumaila et al. 2010). Another important role of the government is to regulate fisheries through laws and regulations, such as quotas and other technical measures. The laws and regulations could be analyzed to offer a complementary perspective on the policy directions during the study period (Hentati-Sundberg and Hjelm 2014, Stoll et al. 2016). We anticipate that a long-term analysis of Swedish fisheries regulations would pick up a similar trend as the subsidy analysis, with initially very few regulations, and in the most recent few years a greening trend representing the rising sustainability awareness.

Several factors seem to have contributed to path dependency in our fisheries management system. Many of the subsidy programs were set up to be long-term and thereby resistant to changing political winds. Payments to the industry did not need to be decided by the parliament on an annual basis, instead pointwise large investments were made in government-run "capital funds" that operated in parallel with the yearly budget negotiations. The stability of actor constellations within policy formulation created increasing benefits for the actors within the policy subsystem, and at the same time a marginalization of any opposing interest or worldviews that could have proposed alternative trajectories. Needless to say, neither the ecosystems themselves nor coming generations were represented in the tight interest coalitions that were set up to promote technological progress, cheap nutrition, export incomes, and stable income levels for fishermen.

Complementary evidence suggests that stable actor constellations may have been a factor contributing to path dependency in Sweden. In 2011, two senior Swedish Board of Fisheries officials were commissioned to write an epitaph about the agency, discussing the evolution of fisheries management and providing illustrative examples from its 63-year existence. In their summary of the last decades' fisheries policy, they indeed described it as emerging from an "iron triangle" formed by the Swedish Board of Fisheries, the Ministry of Agriculture, and the Swedish Fishermen's Association (Westerberg and Ask 2011). The use of the "iron triangle" metaphor echoes political science research on the ties between the Congress, the bureaucracy, and private interests in the context of defense industry policy in the United States (Adams 1981). It has been used to describe the everincreasing defense budget as a result of a policy subgovernment, emerging from the mutual interest of the three actors to maintain the status quo, and thus to detach policy from influence from the parliament (Adams 1981). Our data show that the management authorities have been so strongly involved in industry development that it has served largely as a support function rather than a regulator; industry representatives were also on the board of the Swedish Board of Fisheries from its establishment in 1948 until the early 2000s (Ask et al. 2015). Earlier examples of such interwoven roles and responsibilities between fishing industries and national agencies include the French governmental research institute IFREMER leading the development of driftnet fishing for tuna in the Bay of Biscay in the 1980s, resulting in stock depletion, massive bycatches, and conflicts with traditional fishing practices (Lequesne 2004), and Finley's (2011) work on how the U.S. government in the early 1900s supported long distance tuna fisheries, triggering conflict with coastal states and contributing to overfishing.

\section{Path dependency and sustainability}

How has path-dependency in the policy subsystem influenced sustainability? We suggest a pivotal role of the iron triangle in driving the historical overexploitation. The increasing subsidy levels and corresponding fleet size increase observed until the late 1980 s in effect detached the profitability of the fishing industry from the state of the ecosystems. In the language of economics, the ecosystems were externalized. At the same time could money transfers from the government ensure continued support for the status quo both within the growing bureaucracy (the agency) and the industry? We illustrate these stabilizing feedbacks in Fig. 8A. We acknowledge that such strong industry-government ties have had a role in many parts of Swedish governance (Lewin and Lindvall 2015), in fact fishing has been governed as just another sector and promoted and supported in the same way as has been (more or less) working for other sectors of the society.

We also acknowledge that many other countries and regions have had similar trajectories in fisheries with industry expansion policies gradually replaced by a rational exploitation focus with varying degree of success (Finley 2011, Österblom and Folke 2015). A fair question to ask is whether there were any perceivable alternatives that could have changed the trajectory of Swedish policy during the study period? We argue that although there are many similarities between countries and regions, especially in terms of the fisheries expansion policies after World War 2, many countries have actually initiated reforms because of the low social, economic, and ecological performance of these policies. Examples include the early 1980s transition to transferable quotas in Iceland to increase efficiency and reduce overcapacity (Arnason 2005) and the decentralization policies aimed at involving a broader set of stakeholders in fisheries decision making in the $\mathrm{U}$. S. and Canada since the 1970s (Pomeroy and Berkes 1997). A recent study also has shown convincingly that path dependency can result in alternative stable states as a result of slow institutional change and exclusive harvesting rights, as in this study (Tekwa et al. 2019). Our conclusion also reinforces earlier studies pointing at path dependency as a major force preventing change in fisheries management systems, inside and outside the EU (e.g., Hegland and Raakjæer 2008, Jacobsen 2019).

Standing out in our study is the rapidly increasing cost of fisheries management and research: current numbers are 28\% (total expenditure) and 23\% (management cost) of the gross landing value of the Swedish fishery ${ }^{[1]}$. Comparable numbers reported for Iceland, Norway, and the Newfoundland at the end of the 1990s were $3 \%, 10 \%$, and $15-25 \%$, respectively (Arnason et al. 2000). Our analysis omits costs for the Coastguard and the fisheries section at the Ministry, suggesting that the current Swedish fisheries management is some of the costliest ever reported (Arnason et al. 2000). Whether these high costs are motivated is 
Fig. 8. Conceptual model of (A) the main dynamics for the pre-EU period as described in this paper, and (B) a possible alternative system dynamic without subsidies. In (A), the "iron triangle" of the government, the agency, and the industry creates a reinforcing feedback that boosts the size of the industry and simultaneously the need for regulation, resulting in an increased bureaucracy. By consequence, the environment is externalized. In (B), fleet subsidies are suspended, and the size of the industry is more directly dependent on the ecosystem. Consequently, the iron triangle is replaced by a social-ecological (re) connection, with the ecosystem internalized and thereby possibly fostering resource stewardship among the industry actors.

(a) Iron triangle

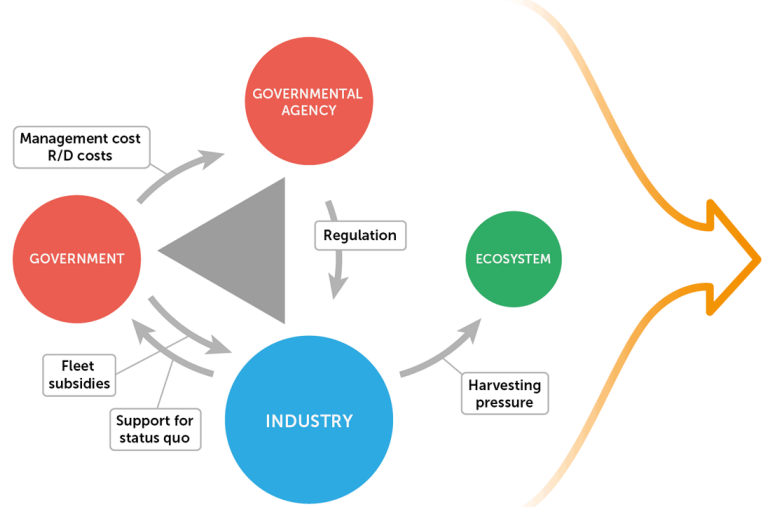

(b) Social-ecological connection



in the end a matter of societal priorities. Somewhat provokingly, one could ask whether coalitions between EU institutions and national and international research institutes can create a new form a path dependency with ever-increasing spending on research and management.

\section{The future}

A long-term sustainable fishery requires an institutional framework that identifies and acts on signals from the ecosystem (Wilson 2006, Crona et al. 2016). Whether these actions are best mediated through formal institutions (as is the setup in most European fisheries) or through self-organized communities or industries will depend on specific circumstances and will likely need to vary from fishery to fishery (Mahon et al. 2008). What is a general feature, however, is the need to create incentive structures that promote learning and adaptability to the variability of ecosystems and discourage short-sightedness, overinvestment, and overexploitation. Here, elimination of capacity enhancing subsidies must be a key priority for government officials in the coming years. It is therefore a worrying signal that the EU parliament on 4 April 2019 voted for the reintroduction of vessel construction subsidies from 2021, a position that awaits the response from the EU Council of Ministers.

We sketch out an alternative fisheries management system configuration where the environment is internalized as a socialecological (re)connection (Fig. 8B), alluding to calls for human reconnection to the biosphere (Folke et al. 2011). In this systems configuration, fishing actors' profitability is directly linked to the state of the ecosystem, something that is expected to increase support for monitoring, enforcement, and precautionary regulatory measures. Acquiring a balance between fishing fleet size and fishing opportunities, finding strategies to increase prices, lower the cost of effort, and increase understanding for the underlying ecosystem are possible long-term effects of a gradual reconnection policy for fisheries. In the long term, rebuilt ecosystems will create increased social and economic benefits that will also reduce the relative cost of management and enforcement. These feedbacks resemble how fisheries policy in Norway and North America has been described earlier, in contrast to the European Union, which has had persistent problems with overcapacity, noncompliance, and low scientific legitimacy (cf. Figs 1 and 2 in Österblom et al. 2011).

We argue that some signs of change in this direction are already visible within EU and in Sweden. The strong actor constellations in Sweden have loosened, partly through the replacement of the Swedish Board of Fisheries with the Swedish Agency for Marine and Water management in 2011 (Österblom et al. 2017). In the $\mathrm{EU}$, one of the main targets behind the most recent Common Fisheries Policy reform was to decrease the regulation burden (micromanagement) on the fishing industry that has arisen as a response to overfishing, in turn (as suggested by this paper) resulting from the expansive national policies put forward by national governments during the 20th century. Another concrete action in the 2013 version of the Common Fisheries Policy is the regionalization, meaning that some of the responsibility of the centralized EU administration is distributed to regional bodies (Symes 2012). At the same time, fishing businesses are increasingly transnational with a low number of globally dominant actors (Österblom et al. 2015). In light of these changes we see a new possible governance trajectory with a diminished role for national governments and an increase of business or community-driven initiatives.

[1] Comparison made for year 2013, which is the last year of available landing data. 
Responses to this article can be read online at:

http://www.ecologyandsociety.org/issues/responses. php/11259

\section{Acknowledgments:}

Part of this article is based on a BSc by Katharina Fryers-Hellqvist, presented at Stockholm University 2014. Rodney Edvinsson provided historical data for the econometric analyses. Data on fisheries subsidies in the EU period was provided by Nils Mulvad and the Swedish Board of Agriculture. The library at Institute of Marine Research (Lysekil), Statistics Sweden library, Stockholm University library, School of Business in Gothenburg library, and the Riksdag library in Stockholm provided invaluable source material for this article. Lars Ask and Tore Gustavsson provided useful input and case study details. Joakim Hjelm, Tim Daw, and two anonymous reviewers provided useful comments on earlier versions of the manuscript.

\section{LITERATURE CITED}

Adams, G. 1981. The iron triangle. Council of Economic Priorities, New York, New York, USA.

Arnason, R. 2005. Property rights in fisheries: Iceland's experience with ITQs. Reviews in Fish Biology and Fisheries 15 (3):243-264. https://doi.org/10.1007/s11160-005-5139-6

Arnason, R., R. Hannesson, and W. E. Schrank. 2000. Costs of fisheries management: the cases of Iceland, Norway and Newfoundland. Marine Policy 24(3):233-243. https://doi. org/10.1016/S0308-597X(99)00029-9

Arthur, W. B. 1994. Increasing returns and path dependence in the economy. University of Michigan Press, Ann Arbor, Michigan, USA. https://doi.org/10.3998/mpub.10029

Ask, L., T. Gustavsson, and H. Westerberg. 2015. Varför har fiskeriförvaltningen inte varit lyckosam? Aqua reports 2015:14. Swedish University of Agricultural Sciences, Uppsala, Sweden.

Boonstra, W. J., and F. W. de Boer. 2014. The historical dynamics of social-ecological traps. Ambio 43(3):260-274. https://doi. org/10.1007/s13280-013-0419-1

Borgström, G. 1966. Revolution i världsfisket. LTs, Sweden.

Burnham, K. P., D. R. Anderson, and K. P. Huyvaert. 2011. AIC model selection and multimodel inference in behavioral ecology: some background, observations, and comparisons. Behavioral Ecology and Sociobiology 65(1):23-35. https://doi.org/10.1007/ s00265-010-1029-6

Cheilari, A., J. Guillen, D. Damalas, and T. Barbas. 2013. Effects of the fuel price crisis on the energy efficiency and the economic performance of the European Union fishing fleets. Marine Policy 40(1):18-24. https://doi.org/10.1016/j.marpol.2012.12.006

Costello, C., D. Ovando, T. Clavelle, C. K. Strauss, R. Hilborn, M. C. Melnychuk, T. A. Branch, S. D. Gaines, C. S. Szuwalski, R. B. Cabrai, D. N. Rader, and A. Leland. 2016. Global fishery prospects under contrasting management regimes. Proceedings of the National Academy of Sciences 113(18):5125-5129. https://doi. org/10.1073/pnas.1520420113
Crona, B. I., T. M. Daw, W. Swartz, A. V. Norström, M. Nyström, M. Thyresson, C. Folke, J. Hentati-Sundberg, H. Österblom, L. Deutsch, and M. Troell. 2016. Masked, diluted and drowned out: how global seafood trade weakens signals from marine ecosystems. Fish and Fisheries 17:1175-1182. https://doi. org/10.1111/faf.12109

Duit, A. 2007. Path dependency and institutional change: the case of industrial emission control in Sweden. Public Administration 85(4):1097-1118. https://doi.org/10.1111/j.1467-9299.2007.00687. $\underline{\mathrm{X}}$

Duit, A. 2014. Conclusion: an emerging ecostate? Pages 321-342 in A. Duit, editor. State and environment: the comparative study of environmental governance. MIT Press, Cambridge, Massachusetts, USA. https://doi.org/10.7551/mitpress/9780262$\underline{027120.003 .0012}$

European Commission (EC). 1992. Council Regulation (EEC) No 3760/92 of 20 December 1992 establishing a Community system for fisheries and aquaculture. EU Council, Brussels, Belgium.

European Commission (EC). 2002. Council regulation (EC) No 2371/2002 of 20 December 2002 on the conservation and sustainable exploitation of fisheries resources under the Common Fisheries Policy. EU Council, Brussels, Belgium.

European Commission (EC). 2013. Regulation (EU) No 1380/2013 of the European Parliament and of the Council of 11 December 2013 on the Common Fisheries Policy, amending Council Regulations (EC) No 1954/2003 and (EC) No 1224/2009 and repealing Council Regulations (EC) No 2371/2002 and (EC) No 639/2004 and Council Decision 2004/585/EC. EU Council, Brussels, Belgium.

Finley, C. 2011. All fish in the sea. Maximum sustainable yield and the failure of fisheries management. University of Chicago Press, Chicago, Illinois, USA. https://doi.org/10.7208/chicago/9780226249681.001.0001

Folke, C., S. R. Carpenter, B. Walker, M. Scheffer, T. Elmqvist, L. Gunderson, and C. S. Holling. 2004. Regime shifts, resilience, and biodiversity in ecosystem management. Annual Review of Ecology, Evolution, and Systematics 35(1):557-581. https://doi. org/10.1146/annurev.ecolsys.35.021103.105711

Folke, C., Å. Jansson, J. Rockström, P. Olsson, S. R. Carpenter, F. S. Chapin III, A.-S. Crépin, G. Daily, K. Danell, J. Ebbesson, T. Elmqvist, V. Galaz, F. Moberg, M. Nilsson, H. Österblom, E. Ostrom, A. Persson, G. D. Peterson, S. Polasky, W. Steffen, B. Walker, and F. Westley. 2011. Reconnecting to the Biosphere. Ambio 40(7):719-738. https://doi.org/10.1007/s13280-011-0184$\mathrm{y}$

Food and Agriculture Organization (FAO). 2016. The state of world fisheries in 2015. Contributing to food security and nutrition for all. FAO, Rome, Italy.

Hardin, G. 1968. The tragedy of the commons. Science 162:1243-1248. https://doi.org/10.1126/science.162.3859.1243

Hegland, T. J., and J. Raakjær. 2008. Recovery plans and the balancing of fishing capacity and fishing possibilities: path dependence in the common fisheries policy. Pages 131-159 in S. S. Gezelius and J. Raakjær, editors. Making fisheries management 
work. Implementation of policies for sustainable fishing. Volume 8. Springer, Dordrecht, The Netherlands. https://doi. org/10.1007/978-1-4020-8628-1 5

Hentati-Sundberg, J., and J. Hjelm. 2014. Can fisheries management be quantified? Marine Policy 48:18-20. https://doi. org/10.1016/j.marpol.2014.02.021

Jacobsen, J. 2019. Path dependence in Faroese fisheries (mis) management. Marine Policy 108:103615. https://doi.org/10.1016/ j.marpol.2019.103615

Jones, B. D., F. R. Baumgartner, and J. L. True. 1998. Policy punctuations: U.S. Budget Authority, 1947-1995. Journal of Politics 60(1):1-33. https://doi.org/10.2307/2647999

Kay, A. 2003. Path dependency and the CAP. Journal of European Public Policy 10(3):405-420. https://doi.org/10.1080/1350176032$\underline{000085379}$

Lequesne, C. 2004. The politics of fisheries in the European Union. Manchester University Press, Manchester, UK.

Levin, S. A., T. Xepapadeas, A.-S. Crépin, J. Norberg, A. de Zeeuw, C. Folke, T. P. Hughes, K. Arrow, S. Barrett, G. Daily, P. Ehrlich, N. Kautsky, K. G. Mäler, S. Polasky, M. Troell, J. R. Vincent, and B. Walker. 2013. Social-ecological systems as complex adaptive systems: modeling and policy implications. Environment and Development Economics 18(02):111-132. https:// doi.org/10.1017/S1355770X12000460

Lewin, L., and J. Lindvall. 2015. One hundred years of Swedish economic policy. Pages 578-591 in J. Pierre, editor. The Oxford handbook of Swedish politics. Oxford University Press, Oxford, UK. https://doi.org/10.1093/oxfordhb/9780199665679.013.36

Lotze, H. K., M. Coll, A. M. Magera, C. Ward-Paige, and L. Airoldi. 2011. Recovery of marine animal populations and ecosystems. Trends in Ecology \& Evolution 26(11):595-605. https:// doi.org/10.1016/j.tree.2011.07.008

Mahon, R., P. McConney, and R. N. Roy. 2008. Governing fisheries as complex adaptive systems. Marine Policy 32 (1):104-112. https://doi.org/10.1016/j.marpol.2007.04.011

Mason, F. 2002. The Newfoundland cod stock collapse: a review and analysis of social factors. Electronic Green Journal 1(17).

Nyström, M., A. V. Norström, T. Blenckner, M. de la TorreCastro, J. S. Eklöf, C. Folke, H. Österblom, R. S. Steneck, M. Thyresson, and M. Troell. 2012. Confronting feedbacks of degraded marine ecosystems. Ecosystems 15(5):695-710. https:// doi.org/10.1007/s10021-012-9530-6

Orach, K., and M. Schlüter. 2016. Uncovering the political dimension of social-ecological systems: contributions from policy process frameworks. Global Environmental Change 40:13-25. https://doi.org/10.1016/j.gloenvcha.2016.06.002

Österblom, H., and C. Folke. 2015. Globalization, marine regime shifts and the Soviet Union. Philosophical Transactions of the Royal Society B 370(1659):20130278. https://doi.org/10.1098/ $\underline{\text { rstb. } 2013.0278}$

Österblom, H., J. Hentati-Sundberg, N. Nevonen, and K. Veem. 2017. Tinkering with a tanker-slow evolution of a Swedish ecosystem approach. ICES Journal of Marine Science 74 (1):443-452. https://doi.org/10.1093/icesjms/fsw232
Österblom, H., J.-B. Jouffray, C. Folke, B. I. Crona, M. Troell, A. Merrie, and J. Rockström. 2015. Transnational corporations as 'keystone actors' in marine ecosystems. PLoS ONE 10(5): e0127533. https://doi.org/10.1371/journal.pone.0127533

Österblom, H., M. Sissenwine, D. Symes, M. Kadin, T. M. Daw, and C. Folke. 2011. Incentives, social-ecological feedbacks and European fisheries. Marine Policy 35(5):568-574. https://doi. org/10.1016/j.marpol.2011.01.018

Ostrom, E. 1990. Governing the commons: the evolution of institutions for collective action. Cambridge University Press, Cambridge, UK.

Ostrom, E. 2009. A general framework for analyzing sustainability of social-ecological systems. Science 325 (5939):419-422. https://doi.org/10.1126/science.1172133

Pauly, D. 2006. Major trends in small-scale marine fisheries, with emphasis on developing countries, and some implications for the social sciences. Maritime Studies 4(2):7-22.

Pauly, D., and D. Zeller. 2016. Catch reconstructions reveal that global marine fisheries catches are higher than reported and declining. Nature Communications 7:10244. https://doi. org/10.1038/ncomms 10244

Pierson, P. 2000. Increasing returns, path dependence, and the study of politics. American Political Science Review 94 (2):251-267. https://doi.org/10.2307/2586011

Pierson, P. 2003. Big, slow-moving, and... invisible. Pages 177-207 in J. Mahoney and D. Rueschemeyer, editors. Comparative historical analysis in the social sciences. Cambridge University Press, Cambridge, UK. https://doi.org/10.1017/cbo9780511803963.006

Pomeroy, R. S., and F. Berkes. 1997. Two to tango: the role of government in fisheries co-management. Marine Policy 21 (5):465-480. https://doi.org/10.1016/S0308-597X(97)00017-1

Ricard, D., C. Minto, O. P. Jensen, and J. K. Baum. 2012. Examining the knowledge base and status of commercially exploited marine species with the RAM Legacy Stock Assessment Database. Fish and Fisheries 13(4):380-398. https://doi. org/10.1111/j.1467-2979.2011.00435.x

Sabatier, P. A. 1999. Theories of the policy process. Westview, Boulder, Colorado, USA.

Scheffer, M. 2009. Critical transitions in nature and society. Princeton University Press, Princeton, New Jersey, USA.

Scheffer, M., S. Carpenter, J. A. Foley, C. Folke, and B. Walker. 2001. Catastrophic shifts in ecosystems. Nature 413:591-596. https://doi.org/10.1038/35098000

SFS (Svensk författningssamling). 1994. Lag (1994:1776) om skatt på energi. Finansdepartmentet, Stockholm, Sweden. [online] URL: https://www.riksdagen.se/sv/dokument-lagar/ dokument/svensk-forfattningssamling/lag-19941776-om-skatt-paenergi sfs-1994-1776

Statens Offentliga Utredningar (SOU). 1947. Statens Offentliga Utredningar 1947:2. Betånkande angående fiskerinåringens efterkrigsproblem samt den prisreglerande verksamheten på fiskets område avgivet av 1945 års fiskeriutredning. SOU, Stockholm, Swden. 
Statens Offentliga Utredningar (SOU). 1977. Fiskerinäringen $i$ framtiden. Betänkande av fiskerikommittén. Statens Offentliga Utredningar 1977:74. Allmänna förlaget, Stockholm, Sweden.

Statistics Sweden. 2019. Consumer price index. Statistics Sweden, Stockholm, Sweden.

Stoll, J. S., C. M. Beitl, and J. A. Wilson. 2016. How access to Maine's fisheries has changed over a quarter century: the cumulative effects of licensing on resilience. Global Environmental Change 37:79-91. https://doi.org/10.1016/j.gloenvcha.2016.01.005

Sugihara, G., R. May, H. Ye, C. Hsieh, E. Deyle, M. Fogarty, and S. Munch. 2012. Detecting causality in complex ecosystems. Science 338(6106):496-500. https://doi.org/10.1126/science.1227079

Sumaila, U. R., A. S. Khan, A. J. Dyck, R. Watson, G. Munro, P. Tyedmers, and D. Pauly. 2010. A bottom-up re-estimation of global fisheries subsidies. Journal of Bioeconomics 12:201-225. https://doi.org/10.1007/s10818-010-9091-8

Sumaila, U. R., V. Lam, F. Le Manach, W. Swartz, and D. Pauly. 2016. Global fisheries subsidies: an updated estimate. Marine Policy 69:189-193. https://doi.org/10.1016/j.marpol.2015.12.026

Swedish Board of Fisheries. 1986. Målplan 1986. Swedish Board of Fisheries, Göteborg, Sweden.

Swedish Board of Fisheries. 1998. Fiskeriverket 50 år. Jubileumsskrift om fiskets situation, betydelse och framtidsmöjligheter. Swedish Board of Fisheries, Göteborg, Sweden.

Symes, D. 2012. Regionalising the common fisheries policy: context, content and controversy. Maritime Studies 11(1):6.

Tekwa, E. W., E. P. Fenichel, S. A. Levin, and M. L. Pinsky. 2019. Path-dependent institutions drive alternative stable states in conservation. Proceedings of the National Academy of Sciences 116(2):689-694. https://doi.org/10.1073/pnas.1806852116

Walters, C., and J.-J. Maguire. 1996. Lessons for stock assessment from the northern cod collapse. Reviews in Fish Biology and Fisheries 6:125-137. https://doi.org/10.1007/bf00182340

Watson, R., W. W. L. Cheung, J. A. Anticamara, R. U. Sumaila, D. Zeller, and D. Pauly. 2013. Global marine yield halved as fishing intensity redoubles. Fish and Fisheries 14(4):493-503. https://doi.org/10.1111/j.1467-2979.2012.00483.x

Westerberg, H., and L. Ask. 2011. Staten och fisket. Nedslag $i$ fiskeriförvaltningens historia. Gothenburg, Sweden.

Wilson, J. A. 2006. Matching social and ecological systems in complex ocean fisheries. Ecology and Society 11(1):9. https://doi. org/10.5751/ES-01628-110109 
Appendix 1. Supplementary Methods and Results.

\section{Iron-triangles and subsidies. Understanding the long-term role of the government on Swedish commercial fisheries}

\section{Supplementary methods}

The Swedish entrance in the European Union in 1995 involved a change in that the majority of the fisheries subsidies were from this year transferred directly from the EU Commission to the fishing industry and organizations linked to the fishing industry. In the Swedish national budget, such expenditures are referred to as "Structural grants to the fisheries sector funded by EU" with no further specification. Therefore, we analyzed separately those expenditures based on raw data from the EU Commission and the corresponding Swedish agency, Swedish Board of Agriculture, disaggregated for each individual project. All those subsidies were categorized according to the same categories as the historical subsidies (project assignment to categories in Table A1.3) and aggregated per category and year. Note that whereas the subsidies preceding 1995 were budget posts (i.e. proposed spending) the data for post-1995 EU structural grants were actual spending. Specifically, during parts of the study, some items were officially budgeted 1000 SEK (a very low number), which technically meant that spending was possible if needed. But in line with earlier work that have used budgets to make inference on economic-political change (Bristol, 2009; Furman, 2006; Moehlmann, 1992) we argue that the difference between using data on budget proposals versus real spending make no crucial difference in interpreting long-term trends in different subsidies and their effect on fishing fleets, and ultimately on sustainability.

In 2011, another important change took place: the agency "Swedish Board of Fisheries" was replaced by "Swedish Agency for Marine and Water Management" (SwAM). The new agency had a broader mandate also including water issues and the marine environment, and consequently not all money distributed to this agency was commercial fisheries related. For 2011-2015 we therefore used the Annual reports of the agency to consider only spending directly related to fisheries management and research. 
Table A1.1. Types of subsidies to given to Swedish fisheries, and classification following (Sumaila et al., 2010), description and motivation of the classification. See also Appendix Tables A1.1 and A1.2 with a complete list of all subsidies reported in Swedish budget proposals and from EU structural grants, respectively, and for which years they apply. We combined the two beneficial subsidy categories (1.1) Fisheries management and (1.2) Fishery research into one category, because research activities were often reported as a part of the management activities and thus not tractable through the whole series.

\begin{tabular}{|c|c|c|c|}
\hline Type of subsidy & $\begin{array}{l}\text { Classificatio } \\
\mathrm{n}\end{array}$ & Description & Motivation to classification \\
\hline $\begin{array}{l}1.1 \text { Fisheries } \\
\text { management } \\
\text { programs and } \\
\text { services and } \\
\text { Fisheries Research }\end{array}$ & Beneficial & $\begin{array}{l}\text { Grants to the Swedish Board of Fisheries and its } \\
\text { predecessors. In this, also governmental funded } \\
\text { fisheries research is included. }\end{array}$ & $\begin{array}{l}\text { Fisheries management and research generally aims } \\
\text { at ensuring sustainable exploitation of the resources. } \\
\text { Some of the research has in fact been aiming at } \\
\text { improving commercial fisheries endeavors (c.f. cat } \\
2.5) \text {, but there were not enough details in the data to } \\
\text { distinguish the exact purpose of individual research } \\
\text { activities. }\end{array}$ \\
\hline 2.1 Fuel subsidies & $\begin{array}{l}\text { Capacity- } \\
\text { enhancing }\end{array}$ & $\begin{array}{l}\text { Direct support for fuel purchase and restitution } \\
\text { of fuel tax. The fact that diesel for fishing } \\
\text { vessels (as for other shipping) is excepted from } \\
\text { tax is probably the largest subsidy, it has } \\
\text { however not been quantified in this paper as it is } \\
\text { invisible in the government budget. Thus our } \\
\text { estimate of this is conservative. }\end{array}$ & $\begin{array}{l}\text { Fuel subsidies decrease the operating cost for fishing } \\
\text { vessel which leads to a higher fishing effort than } \\
\text { without subsidies in the short term, and possibly the } \\
\text { indirect effect of higher investment due to higher } \\
\text { profitability of fishing operations. }\end{array}$ \\
\hline $\begin{array}{l}2.2 \text { Vessel } \\
\text { construction } \\
\text { renewal and } \\
\text { modernization } \\
\text { programs }\end{array}$ & $\begin{array}{l}\text { Capacity- } \\
\text { enhancing }\end{array}$ & $\begin{array}{l}\text { Support for vessel construction and vessel } \\
\text { equipment, such as motors, and equipment for } \\
\text { fish catching, on-board processing, } \\
\text { communication and safety equipment. }\end{array}$ & $\begin{array}{l}\text { Vessel subsidies lead to higher investment in the } \\
\text { fishing fleet and thus directly impacting the fleet } \\
\text { size. }\end{array}$ \\
\hline $\begin{array}{l}2.3 \text { Fishing port } \\
\text { construction and } \\
\text { renovation } \\
\text { programs }\end{array}$ & $\begin{array}{l}\text { Capacity- } \\
\text { enhancing }\end{array}$ & $\begin{array}{l}\text { Grant towards construction of new ports and } \\
\text { renovation/reparation of old ports }\end{array}$ & $\begin{array}{l}\text { Port subsidies supports the infrastructure necessary } \\
\text { for commercial fishing operations and thus lead to } \\
\text { increased total fishing capacity. }\end{array}$ \\
\hline $\begin{array}{l}2.4 \text { Price and } \\
\text { marketing support, } \\
\text { processing and } \\
\text { storage } \\
\text { infrastructure } \\
\text { programs }\end{array}$ & $\begin{array}{l}\text { Capacity- } \\
\text { enhancing }\end{array}$ & $\begin{array}{l}\text { Two types of support that are relatively different } \\
\text { are aggregated in this category: (1) Direct } \\
\text { market support, and (2) Support to processing } \\
\text { and storage infrastructure. Direct market support } \\
\text { has taken various forms, including fixed or } \\
\text { variable amounts paid to fishers by kilo of fish } \\
\text { caught, or special export grants for fish. } \\
\text { Processing and storage infrastructure include } \\
\text { support for building and renovating all types of } \\
\text { fisheries infrastructure that is not onboard of } \\
\text { vessels (cat. 2.2) and that is not in ports (cat. } \\
\text { 2.3), e.g. fish processing facilities. }\end{array}$ & $\begin{array}{l}\text { Price regulation directly influence the cost-benefit } \\
\text { equilibrium of individual fishing operations and thus } \\
\text { lead to higher fishing effort. Processing and storage } \\
\text { infrastructure is a condition for profitable fishing } \\
\text { operations and government-supported investments } \\
\text { will lead to a higher profitability for the sector. }\end{array}$ \\
\hline $\begin{array}{l}2.5 \text { Fishery } \\
\text { development } \\
\text { projects and } \\
\text { support services }\end{array}$ & $\begin{array}{l}\text { Capacity- } \\
\text { enhancing }\end{array}$ & $\begin{array}{l}\text { This category includes various types of support } \\
\text { to the fishing sector, often presented as } \\
\text { development projects, with an active } \\
\text { involvement by the government. Examples } \\
\text { include development of new fishing gears, } \\
\text { fishing areas and processing methods, but could } \\
\text { also be more direct support to fishing } \\
\text { endeavours such as ice-breaking or supply ships } \\
\text { for distant water fisheries. }\end{array}$ & $\begin{array}{l}\text { These subsidies aim at developing fishing new types } \\
\text { of fishing activities, processing techniques or } \\
\text { markets, thereby directly leading to increased fishing } \\
\text { effort. }\end{array}$ \\
\hline $\begin{array}{l}3.1 \text { Fisher } \\
\text { assistance program }\end{array}$ & Ambiguous & $\begin{array}{l}\text { Fisher assistance programs aim at providing } \\
\text { support to fishers during bad times, temporarily } \\
\text { or permanently. Example include support to the } \\
\text { unemployment fund and transition support for } \\
\text { retraining commercial fishers in other } \\
\text { businesses. }\end{array}$ & $\begin{array}{l}\text { These subsidies provide financial security for fishers } \\
\text { to not fish, and thereby leads to decreased fishing } \\
\text { effort. On the other hand, fishers' knowledge about } \\
\text { such government-aided security may lead to over- } \\
\text { investment in fishing capacity. It is therefore } \\
\text { classified as an ambiguous subsidy. }\end{array}$ \\
\hline $\begin{array}{l}3.2 \text { Vessel buyback } \\
\text { programs }\end{array}$ & Ambiguous & $\begin{array}{l}\text { Grants paid out in exchange for vessel } \\
\text { decommissioning/scrapping. }\end{array}$ & $\begin{array}{l}\text { According to a similar logic as for (3.1), vessel } \\
\text { decommissioning can lead to an effort decrease, but } \\
\text { also to over-investment. Experience also show that } \\
\text { money used for decommissioning has often been } \\
\text { used for construction of new vessels; this has even } \\
\text { been one of the goals of Swedish decommission } \\
\text { policy in some periods (SOU, 1992) }\end{array}$ \\
\hline
\end{tabular}


Table A1.2. All grants to the fishing industry and fisheries management as reported in the budget proposals for the Swedish government 1914-2015, their year of availability and their categorization into descriptive and normative categories according to Sumaila et al. 2010.

\begin{tabular}{|c|c|c|c|}
\hline Budget post & Category (description) & $\begin{array}{l}\text { Category } \\
\text { (normative) }\end{array}$ & Years \\
\hline Education of fisheries managers & $\begin{array}{l}\text { 1.1. Fisheries management } \\
\text { programs and services }\end{array}$ & Beneficial & 1953-1966 \\
\hline Fisheries superintendents: operating costs & $\begin{array}{l}\text { 1.1. Fisheries management } \\
\text { programs and services }\end{array}$ & Beneficial & $1948-1968$ \\
\hline Fisheries superintendents: salaries & $\begin{array}{l}\text { 1.1. Fisheries management } \\
\text { programs and services }\end{array}$ & Beneficial & 1948-1991 \\
\hline Glass eel collection station in Trollhättan & $\begin{array}{l}\text { 1.1. Fisheries management } \\
\text { programs and services }\end{array}$ & Beneficial & 1921 \\
\hline Local fisheries managers & $\begin{array}{l}\text { 1.1. Fisheries management } \\
\text { programs and services }\end{array}$ & Beneficial & $\begin{array}{l}1922-1929 \\
1931-1934\end{array}$ \\
\hline $\begin{array}{l}\text { Surveillance for mitigating negative impacts on } \\
\text { fisheries through water pollution }\end{array}$ & $\begin{array}{l}\text { 1.1. Fisheries management } \\
\text { programs and services }\end{array}$ & Beneficial & $1938-1941$ \\
\hline The fisheries management authority: Material & $\begin{array}{l}\text { 1.1. Fisheries management } \\
\text { programs and services }\end{array}$ & Beneficial & 1942 \\
\hline $\begin{array}{l}\text { The fisheries management authority: Operating } \\
\text { costs }\end{array}$ & $\begin{array}{l}\text { 1.1. Fisheries management } \\
\text { programs and services }\end{array}$ & Beneficial & $1942-1948$ \\
\hline The fisheries management authority: salaries & $\begin{array}{l}\text { 1.1. Fisheries management } \\
\text { programs and services }\end{array}$ & Beneficial & $1942-1948$ \\
\hline $\begin{array}{l}\text { The Swedish Board of Fisheries, the fisheries } \\
\text { inspection unit: operating costs }\end{array}$ & $\begin{array}{l}\text { 1.1. Fisheries management } \\
\text { programs and services }\end{array}$ & Beneficial & $1958-1966$ \\
\hline $\begin{array}{l}\text { The Swedish Board of Fisheries, the fisheries } \\
\text { inspection unit: salaries }\end{array}$ & $\begin{array}{l}\text { 1.1. Fisheries management } \\
\text { programs and services }\end{array}$ & Beneficial & $1958-1966$ \\
\hline The Swedish Board of Fisheries: inventories & $\begin{array}{l}\text { 1.1. Fisheries management } \\
\text { programs and services }\end{array}$ & Beneficial & 1947 \\
\hline The Swedish Board of Fisheries: operation costs & $\begin{array}{l}\text { 1.1. Fisheries management } \\
\text { programs and services }\end{array}$ & Beneficial & $1948-1968$ \\
\hline The Swedish Board of Fisheries: salaries & $\begin{array}{l}\text { 1.1. Fisheries management } \\
\text { programs and services }\end{array}$ & Beneficial & $1948-2015$ \\
\hline Fisheries research vessel & 1.2. Fishery R\&D & Beneficial & $1970-1974$ \\
\hline $\begin{array}{l}\text { Hydrographical-biological research for Swedish } \\
\text { waters. }\end{array}$ & 1.2. Fishery R\&D & Beneficial & $\begin{array}{l}\text { 1914-1921, } \\
1926\end{array}$ \\
\hline $\begin{array}{l}\text { Hydrographical-biological research for Swedish } \\
\text { waters. Contribution to international research } \\
\text { station for hydrographical-biological research }\end{array}$ & 1.2. Fishery R\&D & Beneficial & $1926-1934$ \\
\hline $\begin{array}{l}\text { Hydrographical-biological research for Swedish } \\
\text { waters. Hydrographical data collection }\end{array}$ & 1.2. Fishery $R \& D$ & Beneficial & $1922-1934$ \\
\hline $\begin{array}{l}\text { Hydrographical-biological research for Swedish } \\
\text { waters. Insurance for research vessel. }\end{array}$ & 1.2. Fishery R\&D & Beneficial & $1914-1922$ \\
\hline $\begin{array}{l}\text { Hydrographical-biological research for Swedish } \\
\text { waters. Operating cost for research vessel } \\
\text { Eystrasalt. }\end{array}$ & 1.2. Fishery R\&D & Beneficial & $1914-1934$ \\
\hline $\begin{array}{l}\text { Hydrographical-biological research for Swedish } \\
\text { waters. Research }\end{array}$ & 1.2. Fishery R\&D & Beneficial & $1922-1944$ \\
\hline $\begin{array}{l}\text { Hydrographical-biological research for Swedish } \\
\text { waters. Research vessel Skagerak. }\end{array}$ & 1.2. Fishery R\&D & Beneficial & $1914-1935$ \\
\hline Re-introduction of European plaice & 1.2. Fishery R\&D & Beneficial & $1935-1938$ \\
\hline $\begin{array}{l}\text { State owned fisheries research vessel: operating } \\
\text { costs }\end{array}$ & 1.2. Fishery R\&D & Beneficial & $1936-1947$ \\
\hline $\begin{array}{l}\text { State owned fisheries research vessel: other } \\
\text { costs }\end{array}$ & 1.2. Fishery R\&D & Beneficial & 1940,1945 \\
\hline State owned fisheries research vessel: salaries & 1.2. Fishery R\&D & Beneficial & $1936-1947$ \\
\hline Remedy to fishermen for fuel tax payment & 2.1. Fuel Subsidies & $\begin{array}{l}\text { Capacity- } \\
\text { enhancing }\end{array}$ & $\begin{array}{l}\text { 1935-1951, } \\
1952-1981\end{array}$ \\
\hline Loans for vessel construction and modernization & $\begin{array}{l}\text { 2.2. Boat construction, renewal } \\
\text { and modernization programs }\end{array}$ & $\begin{array}{l}\text { Capacity- } \\
\text { enhancing }\end{array}$ & $\begin{array}{l}1919,1921, \\
1931,1933- \\
1934,1937, \\
1949,1951- \\
1956,1958- \\
1993\end{array}$ \\
\hline
\end{tabular}




\begin{tabular}{|c|c|c|c|}
\hline $\begin{array}{l}\text { Support for radiotelegraph and radiotelephone } \\
\text { equipment on fishing vessels }\end{array}$ & $\begin{array}{l}\text { 2.2. Boat construction, renewal } \\
\text { and modernization programs }\end{array}$ & $\begin{array}{l}\text { Capacity- } \\
\text { enhancing }\end{array}$ & $1950-1969$ \\
\hline Port construction & $\begin{array}{l}\text { 2.3. Fishing port construction and } \\
\text { renovation programs }\end{array}$ & $\begin{array}{l}\text { Capacity- } \\
\text { enhancing }\end{array}$ & $1914-1919$ \\
\hline $\begin{array}{l}\text { Port construction in Östra torp (Malmöhus } \\
\text { county) }\end{array}$ & $\begin{array}{l}\text { 2.3. Fishing port construction and } \\
\text { renovation programs }\end{array}$ & $\begin{array}{l}\text { Capacity- } \\
\text { enhancing }\end{array}$ & 1914,1917 \\
\hline Support for minor fishing port facilities & $\begin{array}{l}\text { 2.3. Fishing port construction and } \\
\text { renovation programs }\end{array}$ & $\begin{array}{l}\text { Capacity- } \\
\text { enhancing }\end{array}$ & 1919 \\
\hline Bonus for onboard salting of North Sea herring & $\begin{array}{l}\text { 2.4. Marketing and Storage } \\
\text { infrastructure }\end{array}$ & $\begin{array}{l}\text { Capacity- } \\
\text { enhancing }\end{array}$ & 1948 \\
\hline $\begin{array}{l}\text { Costs for quality control at fish and fish product } \\
\text { exports }\end{array}$ & $\begin{array}{l}\text { 2.4. Marketing and Storage } \\
\text { infrastructure }\end{array}$ & $\begin{array}{l}\text { Capacity- } \\
\text { enhancing }\end{array}$ & 1950 \\
\hline Grants for regulating the trade of fresh herring & $\begin{array}{l}\text { 2.4. Marketing and Storage } \\
\text { infrastructure }\end{array}$ & $\begin{array}{l}\text { Capacity- } \\
\text { enhancing }\end{array}$ & $1938-1946$ \\
\hline Loans for processing and marketing of fish & $\begin{array}{l}\text { 2.4. Marketing and Storage } \\
\text { infrastructure }\end{array}$ & $\begin{array}{l}\text { Capacity- } \\
\text { enhancing }\end{array}$ & $\begin{array}{l}\text { 1941-1943, } \\
1945-1949, \\
1951-1953, \\
1957,1962- \\
1983\end{array}$ \\
\hline Market support to the fishing industry & $\begin{array}{l}\text { 2.4. Marketing and Storage } \\
\text { infrastructure }\end{array}$ & $\begin{array}{l}\text { Capacity- } \\
\text { enhancing }\end{array}$ & $1977-1993$ \\
\hline Support for processing and marketing of fish & $\begin{array}{l}\text { 2.4. Marketing and Storage } \\
\text { infrastructure }\end{array}$ & $\begin{array}{l}\text { Capacity- } \\
\text { enhancing }\end{array}$ & $\begin{array}{l}1935-1941 \\
1957-1959\end{array}$ \\
\hline $\begin{array}{l}\text { An armed steam ship to support and protect } \\
\text { Swedish fishing fleets }\end{array}$ & $\begin{array}{l}\text { 2.5. Fishery development } \\
\text { projects and support services }\end{array}$ & $\begin{array}{l}\text { Capacity- } \\
\text { enhancing }\end{array}$ & $\begin{array}{l}\text { 1914-1915, } \\
1920-1932\end{array}$ \\
\hline $\begin{array}{l}\text { Bonus for participation in herring fisheries is } \\
\text { Iceland }\end{array}$ & $\begin{array}{l}\text { 2.5. Fishery development } \\
\text { projects and support services }\end{array}$ & $\begin{array}{l}\text { Capacity- } \\
\text { enhancing }\end{array}$ & $\begin{array}{l}1937-1939 \\
1945-1947\end{array}$ \\
\hline $\begin{array}{l}\text { Compensation to private water owners for } \\
\text { commercial fishing }\end{array}$ & $\begin{array}{l}\text { 2.5. Fishery development } \\
\text { projects and support services }\end{array}$ & $\begin{array}{l}\text { Capacity- } \\
\text { enhancing }\end{array}$ & $\begin{array}{l}1933-1951 \\
1953-1995\end{array}$ \\
\hline Courses for fishermen & $\begin{array}{l}\text { 2.5. Fishery development } \\
\text { projects and support services }\end{array}$ & $\begin{array}{l}\text { Capacity- } \\
\text { enhancing }\end{array}$ & $1970-1983$ \\
\hline $\begin{array}{l}\text { Coverage for losses for governmental credits to } \\
\text { fishermen }\end{array}$ & $\begin{array}{l}\text { 2.5. Fishery development } \\
\text { projects and support services }\end{array}$ & $\begin{array}{l}\text { Capacity- } \\
\text { enhancing }\end{array}$ & $\begin{array}{l}1970-1985 \\
1990\end{array}$ \\
\hline $\begin{array}{l}\text { Fisheries sector support: fisheries support in } \\
\text { places of particular importance }\end{array}$ & $\begin{array}{l}\text { 2.5. Fishery development } \\
\text { projects and support services }\end{array}$ & $\begin{array}{l}\text { Capacity- } \\
\text { enhancing }\end{array}$ & $1923-1957$ \\
\hline Fishing industry & $\begin{array}{l}\text { 2.5. Fishery development } \\
\text { projects and support services }\end{array}$ & $\begin{array}{l}\text { Capacity- } \\
\text { enhancing }\end{array}$ & 1930 \\
\hline $\begin{array}{l}\text { Fishing vessel and fishing gear insurances: } \\
\text { organization support }\end{array}$ & $\begin{array}{l}\text { 2.5. Fishery development } \\
\text { projects and support services }\end{array}$ & $\begin{array}{l}\text { Capacity- } \\
\text { enhancing }\end{array}$ & $\begin{array}{l}1949,1951- \\
1953,1957\end{array}$ \\
\hline $\begin{array}{l}\text { Fishing vessel and fishing gear insurances: } \\
\text { support at insurance losses }\end{array}$ & $\begin{array}{l}\text { 2.5. Fishery development } \\
\text { projects and support services }\end{array}$ & $\begin{array}{l}\text { Capacity- } \\
\text { enhancing }\end{array}$ & $\begin{array}{l}1949,1951- \\
1953,1957- \\
1958,1960- \\
1961\end{array}$ \\
\hline General support to the fishing industry & $\begin{array}{l}\text { 2.5. Fishery development } \\
\text { projects and support services }\end{array}$ & $\begin{array}{l}\text { Capacity- } \\
\text { enhancing }\end{array}$ & $\begin{array}{l}\text { 1914-1929, } \\
1931-1993\end{array}$ \\
\hline $\begin{array}{l}\text { Grants for the arrangement of navigation courses } \\
\text { for fishers in the Bohuslän county }\end{array}$ & $\begin{array}{l}\text { 2.5. Fishery development } \\
\text { projects and support services }\end{array}$ & $\begin{array}{l}\text { Capacity- } \\
\text { enhancing }\end{array}$ & $1914-1926$ \\
\hline $\begin{array}{l}\text { Grants to "Svenska Fiskarenas studieförbund" } \\
\text { (The Swedish fishers' educational association) }\end{array}$ & $\begin{array}{l}\text { 2.5. Fishery development } \\
\text { projects and support services }\end{array}$ & $\begin{array}{l}\text { Capacity- } \\
\text { enhancing }\end{array}$ & 1947 \\
\hline Ice-breaking support to the fishing sector & $\begin{array}{l}\text { 2.5. Fishery development } \\
\text { projects and support services }\end{array}$ & $\begin{array}{l}\text { Capacity- } \\
\text { enhancing }\end{array}$ & $1945-1993$ \\
\hline Loans for fishing gears & $\begin{array}{l}\text { 2.5. Fishery development } \\
\text { projects and support services }\end{array}$ & $\begin{array}{l}\text { Capacity- } \\
\text { enhancing }\end{array}$ & $\begin{array}{l}\text { 1939-1940, } \\
1947,1961- \\
1962,1972- \\
1977,1980- \\
1982\end{array}$ \\
\hline Safety equipment for fishing vessel navigation & $\begin{array}{l}\text { 2.5. Fishery development } \\
\text { projects and support services }\end{array}$ & $\begin{array}{l}\text { Capacity- } \\
\text { enhancing }\end{array}$ & $1936-1956$ \\
\hline Support for fisheries in distant waters & $\begin{array}{l}\text { 2.5. Fishery development } \\
\text { projects and support services }\end{array}$ & $\begin{array}{l}\text { Capacity- } \\
\text { enhancing }\end{array}$ & $\begin{array}{l}1937-1938 \\
1946-1969\end{array}$ \\
\hline $\begin{array}{l}\text { Support for the "Södra Sveriges fiskeriförening" } \\
\text { (the South Sweden fisheries association) }\end{array}$ & $\begin{array}{l}\text { 2.5. Fishery development } \\
\text { projects and support services }\end{array}$ & $\begin{array}{l}\text { Capacity- } \\
\text { enhancing }\end{array}$ & $1914-1934$ \\
\hline $\begin{array}{l}\text { Support to fishermen due to loss or destruction } \\
\text { of fishing gear }\end{array}$ & $\begin{array}{l}\text { 2.5. Fishery development } \\
\text { projects and support services }\end{array}$ & $\begin{array}{l}\text { Capacity- } \\
\text { enhancing }\end{array}$ & $\begin{array}{l}\text { 1935-1939, } \\
1958-1961\end{array}$ \\
\hline Support vessel for Iceland herring fisheries & $\begin{array}{l}\text { 2.5. Fishery development } \\
\text { projects and support services }\end{array}$ & $\begin{array}{l}\text { Capacity- } \\
\text { enhancing }\end{array}$ & $1950-1969$ \\
\hline
\end{tabular}




\begin{tabular}{|c|c|c|c|}
\hline Loans to shrimp fishers & 3.1. Fisher assistance programs & Ambiguous & $1964-1965$ \\
\hline Special support to the fishing sector & 3.1. Fisher assistance programs & Ambiguous & 1994 \\
\hline Special transition support for fishermen & 3.1. Fisher assistance programs & Ambiguous & $1969-1978$ \\
\hline Support for fishermen & 3.1. Fisher assistance programs & Ambiguous & $\begin{array}{l}1934,1939- \\
1943\end{array}$ \\
\hline $\begin{array}{l}\text { Support for fishers at cancellation of previously } \\
\text { sued fishing waters }\end{array}$ & 3.1. Fisher assistance programs & Ambiguous & $1970-1983$ \\
\hline Support for shrimp fishers & 3.1. Fisher assistance programs & Ambiguous & $1964-1965$ \\
\hline $\begin{array}{l}\text { Support to fishermen on the South and East } \\
\text { coast and on Gotland }\end{array}$ & 3.1. Fisher assistance programs & Ambiguous & 1994 \\
\hline Support for fisheries rationalization etc. & 3.2. Vessel buyback programs & Ambiguous & $1979-1993$ \\
\hline $\begin{array}{l}\text { Support for the "Södra Sveriges fiskeriförening" } \\
\text { (the South Sweden fisheries association). } \\
\text { Housing for the manager. }\end{array}$ & $\begin{array}{l}\text { X. Aquaculture (not included in } \\
\text { analysis) }\end{array}$ & $N A$ & $1930-1931$ \\
\hline $\begin{array}{l}\text { Support for the "Södra Sveriges fiskeriförening" } \\
\text { (the South Sweden fisheries association). Setting } \\
\text { up aquaculture production facilities. }\end{array}$ & $\begin{array}{l}X \text {. Aquaculture (not included in } \\
\text { analysis) }\end{array}$ & $N A$ & 1928-1929 \\
\hline $\begin{array}{l}\text { Costs for fisheries investigation in water } \\
\text { management court cases }\end{array}$ & $\begin{array}{l}\text { X. Freshwater fisheries (not } \\
\text { included in analysis) }\end{array}$ & $N A$ & $1969-1983$ \\
\hline $\begin{array}{l}\text { Research and experiment station for freshwater } \\
\text { fisheries: operating costs }\end{array}$ & $\begin{array}{l}\text { X. Freshwater fisheries (not } \\
\text { included in analysis) }\end{array}$ & $N A$ & $1931-1947$ \\
\hline $\begin{array}{l}\text { Research and experiment station for freshwater } \\
\text { fisheries: salaries }\end{array}$ & $\begin{array}{l}\text { X. Freshwater fisheries (not } \\
\text { included in analysis) }\end{array}$ & $N A$ & 1931-1947 \\
\hline $\begin{array}{l}\text { Research within the Freshwater research } \\
\text { laboratory }\end{array}$ & $\begin{array}{l}\text { X. Freshwater fisheries (not } \\
\text { included in analysis) }\end{array}$ & $N A$ & $\begin{array}{l}1950-1958 \\
1960-1969\end{array}$ \\
\hline Recreational fisheries support & $\begin{array}{l}\text { X. Recreational fisheries (not } \\
\text { included in analysis) }\end{array}$ & $N A$ & 1981- 2011 \\
\hline
\end{tabular}

Table A1.3. Grants to the fishing industry and fisheries management from the European fisheries funds 1995 2014 and their categorization into descriptive and normative categories according to Sumaila et al. 2010. Abbreviations for the program periods: FIFG: Financial Instrument for Fisheries Guidance, EFF: European Fisheries Fund.

\begin{tabular}{|c|c|c|c|}
\hline Project description & Category (description) & $\begin{array}{l}\text { Category } \\
\text { normative }\end{array}$ & Program period \\
\hline Common activities & $\begin{array}{l}\text { 1.1. Fisheries management } \\
\text { programs and services }\end{array}$ & Beneficial & EFF2004-2015 \\
\hline Pilot or demonstration projects & $\begin{array}{l}\text { 1.1. Fisheries management } \\
\text { programs and services }\end{array}$ & Beneficial & $\begin{array}{l}\text { FIFG1995-2007 \& } \\
\text { EFF2004-2015 }\end{array}$ \\
\hline Protection of Aquatic resources & $\begin{array}{l}\text { 1.1. Fisheries management } \\
\text { programs and services }\end{array}$ & Beneficial & EFF2004-2015 \\
\hline $\begin{array}{l}\text { Technical Assistance (e.g. } \\
\text { studies, exchange of } \\
\text { experiences, management and } \\
\text { implementation of programmes) }\end{array}$ & $\begin{array}{l}\text { 1.1. Fisheries management } \\
\text { programs and services }\end{array}$ & Beneficial & $\begin{array}{l}\text { FIFG1995-2007 \& } \\
\text { EFF2004-2015 }\end{array}$ \\
\hline $\begin{array}{l}\text { Investments onboard of fishing } \\
\text { vessels }\end{array}$ & $\begin{array}{l}\text { 2.2. Boat construction, renewal } \\
\text { and modernization programs }\end{array}$ & Beneficial & FIFG1995-2007 \\
\hline Change of fishing vessel & $\begin{array}{l}\text { 2.2. Boat construction, renewal } \\
\text { and modernization programs }\end{array}$ & $\begin{array}{l}\text { Capacity- } \\
\text { enhancing }\end{array}$ & EFF2004-2015 \\
\hline Construction of fishing vessels & $\begin{array}{l}\text { 2.2. Boat construction, renewal } \\
\text { and modernization programs }\end{array}$ & $\begin{array}{l}\text { Capacity- } \\
\text { enhancing }\end{array}$ & $\begin{array}{l}\text { FIFG1995-2007 \& } \\
\text { EFF2004-2015 }\end{array}$ \\
\hline $\begin{array}{l}\text { Investments onboard of fishing } \\
\text { vessels (improvement of energy } \\
\text { efficiency, hygiene, onboard } \\
\text { safety, product quality, working } \\
\text { conditions, selectivity and } \\
\text { motor exchange) }\end{array}$ & $\begin{array}{l}\text { 2.2. Boat construction, renewal } \\
\text { and modernization programs }\end{array}$ & $\begin{array}{l}\text { Capacity- } \\
\text { enhancing }\end{array}$ & EFF2004-2015 \\
\hline Modernization of fishing vessel & $\begin{array}{l}\text { 2.2. Boat construction, renewal } \\
\text { and modernization programs }\end{array}$ & $\begin{array}{l}\text { Capacity- } \\
\text { enhancing }\end{array}$ & $\begin{array}{l}\text { FIFG1995-2007 \& } \\
\text { EFF2004-2015 }\end{array}$ \\
\hline $\begin{array}{l}\text { Construction of new port } \\
\text { facilities/extension of existing } \\
\text { port facilities }\end{array}$ & $\begin{array}{l}\text { 2.3. Fishing port construction } \\
\text { and renovation programs }\end{array}$ & $\begin{array}{l}\text { Capacity- } \\
\text { enhancing }\end{array}$ & FIFG1995-2007 \\
\hline Equipment in fishing ports & 2.3. Fishing port construction & Capacity- & EFF2004-2015 \\
\hline
\end{tabular}




\begin{tabular}{|c|c|c|c|}
\hline & and renovation programs & enhancing & \\
\hline Investments in fishing ports & $\begin{array}{l}\text { 2.3. Fishing port construction } \\
\text { and renovation programs }\end{array}$ & $\begin{array}{l}\text { Capacity- } \\
\text { enhancing }\end{array}$ & EFF2004-2015 \\
\hline $\begin{array}{l}\text { Modernisation of existing port } \\
\text { facilities }\end{array}$ & $\begin{array}{l}\text { 2.3. Fishing port construction } \\
\text { and renovation programs }\end{array}$ & $\begin{array}{l}\text { Capacity- } \\
\text { enhancing }\end{array}$ & $\begin{array}{l}\text { FIFG1995-2007 \& } \\
\text { EFF2004-2015 }\end{array}$ \\
\hline $\begin{array}{l}\text { Fish processing and marketing - } \\
\text { construction, equipment or } \\
\text { modernization of sales units }\end{array}$ & $\begin{array}{l}\text { 2.4. Price and marketing support, } \\
\text { processing and storage } \\
\text { infrastructure programs }\end{array}$ & $\begin{array}{l}\text { Capacity- } \\
\text { enhancing }\end{array}$ & $\begin{array}{l}\text { FIFG1995-2007 \& } \\
\text { EFF2004-2015 }\end{array}$ \\
\hline $\begin{array}{l}\text { Fish processing and marketing - } \\
\text { construction, equipment or } \\
\text { modernization of processing } \\
\text { unit }\end{array}$ & $\begin{array}{l}\text { 2.4. Price and marketing support, } \\
\text { processing and storage } \\
\text { infrastructure programs }\end{array}$ & $\begin{array}{l}\text { Capacity- } \\
\text { enhancing }\end{array}$ & $\begin{array}{l}\text { FIFG1995-2007 \& } \\
\text { EFF2004-2015 }\end{array}$ \\
\hline $\begin{array}{l}\text { Promotional activities - advice, } \\
\text { sales support, sales campaigns, } \\
\text { and other services }\end{array}$ & $\begin{array}{l}\text { 2.4. Price and marketing support, } \\
\text { processing and storage } \\
\text { infrastructure programs }\end{array}$ & $\begin{array}{l}\text { Capacity- } \\
\text { enhancing }\end{array}$ & EFF2004-2015 \\
\hline $\begin{array}{l}\text { Promotional activities - market } \\
\text { and consumer surveys, trade } \\
\text { fairs. }\end{array}$ & $\begin{array}{l}\text { 2.4. Price and marketing support, } \\
\text { processing and storage } \\
\text { infrastructure programs }\end{array}$ & $\begin{array}{l}\text { Capacity- } \\
\text { enhancing }\end{array}$ & $\begin{array}{l}\text { FIFG1995-2007 \& } \\
\text { EFF2004-2015 }\end{array}$ \\
\hline $\begin{array}{l}\text { Quality certification and } \\
\text { product labelling operations }\end{array}$ & $\begin{array}{l}\text { 2.4. Price and marketing support, } \\
\text { processing and storage } \\
\text { infrastructure programs }\end{array}$ & $\begin{array}{l}\text { Capacity- } \\
\text { enhancing }\end{array}$ & FIFG1995-2007 \\
\hline $\begin{array}{l}\text { Branch common activities - } \\
\text { establishment of producer } \\
\text { organization (PO) }\end{array}$ & $\begin{array}{l}2.5 \text { Fishery development projects } \\
\text { and support services }\end{array}$ & $\begin{array}{l}\text { Capacity- } \\
\text { enhancing }\end{array}$ & EFF2004-2015 \\
\hline $\begin{array}{l}\text { Branch common activities - } \\
\text { other activities }\end{array}$ & $\begin{array}{l}2.5 \text { Fishery development projects } \\
\text { and support services }\end{array}$ & $\begin{array}{l}\text { Capacity- } \\
\text { enhancing }\end{array}$ & EFF2004-2015 \\
\hline Development of fishing areas & $\begin{array}{l}2.5 \text { Fishery development projects } \\
\text { and support services }\end{array}$ & $\begin{array}{l}\text { Capacity- } \\
\text { enhancing }\end{array}$ & EFF2004-2015 \\
\hline $\begin{array}{l}\text { Operations by members of the } \\
\text { trade (setting up producer } \\
\text { organisations, aid to assist their } \\
\text { drive to improve quality etc.) }\end{array}$ & $\begin{array}{l}2.5 \text { Fishery development projects } \\
\text { and support services }\end{array}$ & $\begin{array}{l}\text { Capacity- } \\
\text { enhancing }\end{array}$ & FIFG1995-2007 \\
\hline $\begin{array}{l}\text { Setting-up aid for young } \\
\text { fishermen }\end{array}$ & $\begin{array}{l}2.5 \text { Fishery development projects } \\
\text { and support services }\end{array}$ & $\begin{array}{l}\text { Capacity- } \\
\text { enhancing }\end{array}$ & $\begin{array}{l}\text { FIFG1995-2007 \& } \\
\text { EFF2004-2015 }\end{array}$ \\
\hline $\begin{array}{l}\text { Support to small-scale coastal } \\
\text { fishing }\end{array}$ & $\begin{array}{l}2.5 \text { Fishery development projects } \\
\text { and support services }\end{array}$ & $\begin{array}{l}\text { Capacity- } \\
\text { enhancing }\end{array}$ & $\begin{array}{l}\text { FIFG1995-2007 \& } \\
\text { EFF2004-2015 }\end{array}$ \\
\hline $\begin{array}{l}\text { Support to small-scale coastal } \\
\text { fishing - integrated and } \\
\text { collective projects }\end{array}$ & $\begin{array}{l}2.5 \text { Fishery development projects } \\
\text { and support services }\end{array}$ & $\begin{array}{l}\text { Capacity- } \\
\text { enhancing }\end{array}$ & EFF2004-2015 \\
\hline $\begin{array}{l}\text { Temporary cessation of } \\
\text { activities and other financial } \\
\text { compensation }\end{array}$ & 3.1. Fisher assistance programs & Ambigous & $\begin{array}{l}\text { FIFG1995-2007 \& } \\
\text { EFF2004-2015 }\end{array}$ \\
\hline $\begin{array}{l}\text { Exportation/Reassignment/Tran } \\
\text { sfer of vessel to third country }\end{array}$ & 3.2. Vessel buyback programs & Ambigous & $\begin{array}{l}\text { FIFG1995-2007 \& } \\
\text { EFF2004-2015 }\end{array}$ \\
\hline $\begin{array}{l}\text { Rebuilding of vessel to non- } \\
\text { fisheries purpose }\end{array}$ & 3.2. Vessel buyback programs & Ambigous & EFF2004-2015 \\
\hline Scrapping of vessel & 3.2. Vessel buyback programs & Ambigous & $\begin{array}{l}\text { FIFG1995-2007 \& } \\
\text { EFF2004-2015 }\end{array}$ \\
\hline $\begin{array}{l}\text { Increase in aquaculture } \\
\text { production capacity }\end{array}$ & $\begin{array}{l}\text { X. Aquaculture (not included in } \\
\text { analysis) }\end{array}$ & $N A$ & $\begin{array}{l}\text { FIFG1995-2007 \& } \\
\text { EFF2004-2015 }\end{array}$ \\
\hline $\begin{array}{l}\text { Increase in number of fish } \\
\text { smolt from hatchery }\end{array}$ & $\begin{array}{l}\text { X. Aquaculture (not included in } \\
\text { analysis) }\end{array}$ & $N A$ & EFF2004-2015 \\
\hline $\begin{array}{l}\text { Modernisation of existing } \\
\text { aquaculture units }\end{array}$ & $\begin{array}{l}\text { X. Aquaculture (not included in } \\
\text { analysis) }\end{array}$ & $N A$ & $\begin{array}{l}\text { FIFG1995-2007 \& } \\
\text { EFF2004-2015 }\end{array}$ \\
\hline Construction of inland vessels & $\begin{array}{l}\text { X. Freshwater fisheries (not } \\
\text { included in the analysis) }\end{array}$ & $N A$ & $\begin{array}{l}\text { FIFG1995-2007 \& } \\
\text { EFF2004-2015 }\end{array}$ \\
\hline Inland fisheries - other activities & $\begin{array}{l}\text { X. Freshwater fisheries (not } \\
\text { included in the analysis) }\end{array}$ & $N A$ & EFF2004-2015 \\
\hline $\begin{array}{l}\text { Investments in inland fisheries } \\
\text { facilities }\end{array}$ & $\begin{array}{l}\text { X. Freshwater fisheries (not } \\
\text { included in the analysis) }\end{array}$ & $N A$ & EFF2004-2015 \\
\hline $\begin{array}{l}\text { Modernisation of inland fishing } \\
\text { vessels }\end{array}$ & $\begin{array}{l}\text { X. Freshwater fisheries (not } \\
\text { included in the analysis) }\end{array}$ & $N A$ & $\begin{array}{l}\text { FIFG1995-2007 \& } \\
\text { EFF2004-2015 }\end{array}$ \\
\hline $\begin{array}{l}\text { Other measures to assist inland } \\
\text { fishing }\end{array}$ & $\begin{array}{l}\text { X. Freshwater fisheries (not } \\
\text { included in the analysis) }\end{array}$ & $N A$ & FIFG1995-2007 \\
\hline
\end{tabular}




\section{Supplementary results}

Table A1.4. Model selection table for statistical models explaining total subsidy levels for 1914-1994. Average parameter values calculated from weighting all models are given in Table A1.6. Only first 30 models shown.

\begin{tabular}{|c|c|c|c|c|c|c|c|c|c|c|c|c|c|c|c|c|}
\hline $\begin{array}{c}\text { Mod } \\
\mathrm{nr}\end{array}$ & Interc & AR1 & AR2 & AR3 & AR4 & AR5 & $\begin{array}{l}\text { dMan } \\
\text { ufact }\end{array}$ & $\begin{array}{c}\text { Land } \\
\text { val }\end{array}$ & Oil & Pol & $\mathrm{Yr}$ & df & logLik & AICC & delta & $\underset{t}{\text { weigh }}$ \\
\hline 1 & 0 & 0.775 & NA & NA & NA & NA & NA & NA & NA & NA & 0.187 & 4 & -29.145 & $\begin{array}{c}66.81 \\
7\end{array}$ & 0 & 0.036 \\
\hline 2 & 0 & 0.671 & NA & NA & NA & NA & NA & NA & 0.085 & NA & 0.235 & 5 & -28.295 & 67.39 & 0.572 & 0.027 \\
\hline 3 & 0 & 0.74 & NA & NA & NA & 0.084 & NA & NA & NA & NA & 0.149 & 5 & -28.388 & $\begin{array}{c}67.57 \\
7\end{array}$ & 0.76 & 0.025 \\
\hline 4 & 0 & 0.641 & NA & NA & NA & 0.08 & NA & NA & 0.082 & NA & 0.198 & 6 & -27.595 & $\begin{array}{c}68.32 \\
5\end{array}$ & 1.508 & 0.017 \\
\hline 5 & 0 & 0.789 & NA & -0.119 & NA & 0.137 & NA & NA & NA & NA & 0.164 & 6 & -27.642 & $\begin{array}{c}68.41 \\
9\end{array}$ & 1.602 & 0.016 \\
\hline 6 & 0 & 0.68 & NA & -0.146 & NA & 0.145 & NA & NA & 0.099 & NA & 0.226 & 7 & -26.483 & 68.5 & 1.683 & 0.015 \\
\hline 7 & 0 & 0.767 & NA & NA & NA & NA & -0.03 & NA & NA & NA & 0.191 & 5 & -28.86 & $\begin{array}{c}68.51 \\
9\end{array}$ & 1.702 & 0.015 \\
\hline 8 & -0.051 & 0.756 & NA & NA & NA & NA & NA & NA & NA & + & 0.192 & 6 & -27.834 & $\begin{array}{c}68.80 \\
3\end{array}$ & 1.986 & 0.013 \\
\hline 9 & 0 & 0.812 & -0.047 & NA & NA & NA & NA & NA & NA & NA & 0.195 & 5 & -29.052 & $\begin{array}{c}68.90 \\
5\end{array}$ & 2.088 & 0.013 \\
\hline 10 & -0.062 & 0.71 & NA & NA & NA & 0.103 & NA & NA & NA & + & 0.146 & 7 & -26.696 & $\begin{array}{c}68.92 \\
6\end{array}$ & 2.109 & 0.013 \\
\hline 11 & 0 & 0.762 & NA & NA & 0.028 & $\mathrm{NA}$ & NA & NA & NA & NA & 0.175 & 5 & -29.071 & $\begin{array}{c}68.94 \\
1\end{array}$ & 2.124 & 0.012 \\
\hline 12 & -0.114 & 0.734 & NA & NA & NA & 0.173 & NA & 0.081 & NA & + & NA & 7 & -26.713 & $\begin{array}{c}68.96 \\
1\end{array}$ & 2.143 & 0.012 \\
\hline 13 & 0 & 0.793 & NA & -0.03 & NA & NA & NA & NA & NA & NA & 0.196 & 5 & -29.082 & $\begin{array}{c}68.96 \\
4\end{array}$ & 2.147 & 0.012 \\
\hline 14 & 0 & 0.824 & NA & NA & NA & 0.137 & NA & NA & NA & NA & NA & 4 & -30.251 & $\begin{array}{c}69.02 \\
8\end{array}$ & 2.211 & 0.012 \\
\hline 15 & 0 & 0.724 & -0.093 & NA & NA & NA & NA & NA & 0.101 & NA & 0.26 & 6 & -27.954 & $\begin{array}{c}69.04 \\
4\end{array}$ & 2.227 & 0.012 \\
\hline 16 & 0 & 0.775 & NA & NA & NA & NA & NA & 0.008 & NA & NA & 0.183 & 5 & -29.126 & $\begin{array}{c}69.05 \\
3\end{array}$ & 2.235 & 0.012 \\
\hline 17 & 0 & 0.716 & -0.146 & NA & NA & 0.107 & NA & NA & 0.105 & NA & 0.225 & 7 & -26.805 & $\begin{array}{c}69.14 \\
5\end{array}$ & 2.328 & 0.011 \\
\hline 18 & 0 & 0.756 & NA & NA & -0.099 & 0.156 & NA & NA & NA & NA & 0.159 & 6 & -28.007 & 69.15 & 2.333 & 0.011 \\
\hline 19 & 0 & 0.807 & -0.097 & NA & NA & 0.103 & NA & NA & NA & NA & 0.159 & 6 & -28.024 & $\begin{array}{c}69.18 \\
3\end{array}$ & 2.366 & 0.011 \\
\hline 20 & 0 & 0.693 & NA & -0.05 & NA & NA & NA & NA & 0.092 & NA & 0.255 & 6 & -28.114 & $\begin{array}{c}69.36 \\
3\end{array}$ & 2.546 & 0.01 \\
\hline 21 & 0 & 0.647 & NA & NA & -0.128 & 0.172 & NA & NA & 0.095 & NA & 0.218 & 7 & -26.959 & $\begin{array}{c}69.45 \\
2\end{array}$ & 2.635 & 0.01 \\
\hline 22 & 0 & 0.674 & NA & NA & $\mathrm{NA}$ & $\mathrm{NA}$ & -0.02 & NA & 0.078 & NA & 0.234 & 6 & -28.171 & $\begin{array}{c}69.47 \\
7\end{array}$ & 2.659 & 0.009 \\
\hline 23 & 0 & 0.734 & NA & NA & NA & 0.08 & -0.026 & NA & NA & NA & 0.155 & 6 & -28.174 & $\begin{array}{c}69.48 \\
3\end{array}$ & 2.666 & 0.009 \\
\hline 24 & 0 & 0.663 & NA & NA & NA & NA & NA & 0.021 & 0.092 & NA & 0.229 & 6 & -28.18 & $\begin{array}{c}69.49 \\
5\end{array}$ & 2.678 & 0.009 \\
\hline 25 & 0 & 0.736 & NA & NA & NA & 0.093 & NA & 0.023 & NA & NA & 0.136 & 6 & -28.256 & $\begin{array}{c}69.64 \\
8\end{array}$ & 2.831 & 0.009 \\
\hline 26 & 0 & 0.667 & NA & NA & 0.014 & NA & NA & NA & 0.083 & NA & 0.228 & 6 & -28.275 & $\begin{array}{c}69.68 \\
6\end{array}$ & 2.869 & 0.009 \\
\hline 27 & -0.085 & 0.692 & NA & NA & NA & 0.131 & NA & 0.059 & NA & + & 0.107 & 8 & -25.874 & $\begin{array}{c}69.74 \\
8\end{array}$ & 2.931 & 0.008 \\
\hline 28 & -0.056 & 0.759 & NA & -0.119 & NA & 0.156 & NA & NA & NA & + & 0.163 & 8 & -25.919 & $\begin{array}{c}69.83 \\
8\end{array}$ & 3.021 & 0.008 \\
\hline 29 & -0.095 & 0.786 & NA & NA & NA & 0.152 & NA & NA & NA & + & NA & 6 & -28.429 & $\begin{array}{c}69.99 \\
3\end{array}$ & 3.176 & 0.007 \\
\hline 30 & 0 & 0.8 & NA & NA & NA & 0.145 & NA & 0.047 & NA & NA & NA & 5 & -29.642 & $\begin{array}{c}70.08 \\
4\end{array}$ & 3.267 & 0.007 \\
\hline
\end{tabular}


Table A1.5. Model selection table for statistical models explaining subsidy colour (fraction beneficial to capacity enhancing subsidies) for 1914-1994. Average parameter values calculated from weighting all models are given in Table A1.7. Only first 30 models shown.

\begin{tabular}{|c|c|c|c|c|c|c|c|c|c|c|c|c|c|c|c|c|}
\hline $\begin{array}{c}\mathrm{Mod} \\
\mathrm{Nr}\end{array}$ & $\begin{array}{c}\text { Inter } \\
\text { c. }\end{array}$ & $\begin{array}{l}\text { dMan } \\
\text { ufact }\end{array}$ & $\begin{array}{c}\text { Land } \\
\text { val }\end{array}$ & Oil & pol & AR1 & AR2 & AR3 & AR4 & AR5 & $\begin{array}{l}Y \\
r\end{array}$ & $\begin{array}{l}d \\
f\end{array}$ & logLik & AICc & delta & $\begin{array}{c}\text { weig } \\
\text { ht }\end{array}$ \\
\hline 1 & $\begin{array}{c}0.34 \\
9\end{array}$ & NA & NA & NA & + & $\begin{array}{c}0.64 \\
1\end{array}$ & NA & NA & NA & NA & $\begin{array}{l}\mathrm{N} \\
\mathrm{A}\end{array}$ & 5 & -74.877 & $\begin{array}{c}160 . \\
55\end{array}$ & 0 & $\begin{array}{c}0.02 \\
3\end{array}$ \\
\hline 2 & $\begin{array}{c}0.37 \\
3\end{array}$ & NA & NA & NA & + & $\begin{array}{c}0.66 \\
9\end{array}$ & NA & NA & NA & $\begin{array}{c}0.10 \\
5\end{array}$ & $\begin{array}{l}\mathrm{N} \\
\mathrm{A}\end{array}$ & 6 & -73.911 & $\begin{array}{c}160 . \\
96\end{array}$ & $\begin{array}{c}0.40 \\
2\end{array}$ & $\begin{array}{c}0.01 \\
9\end{array}$ \\
\hline 3 & 0 & NA & NA & NA & NA & $\begin{array}{c}0.66 \\
7\end{array}$ & $\begin{array}{c}0.21 \\
1\end{array}$ & NA & NA & $\begin{array}{c}0.13 \\
6\end{array}$ & $\begin{array}{l}\mathrm{N} \\
\mathrm{A}\end{array}$ & 5 & -75.113 & $\begin{array}{c}161 . \\
03\end{array}$ & $\begin{array}{c}0.47 \\
3\end{array}$ & $\begin{array}{c}0.01 \\
8\end{array}$ \\
\hline 4 & $\begin{array}{c}0.32 \\
2\end{array}$ & NA & NA & NA & + & $\begin{array}{c}0.58 \\
1\end{array}$ & $\begin{array}{c}0.16 \\
3\end{array}$ & NA & NA & $\begin{array}{c}0.13 \\
9\end{array}$ & $\begin{array}{l}\mathrm{N} \\
\mathrm{A}\end{array}$ & 7 & -72.843 & $\begin{array}{c}161 . \\
22\end{array}$ & $\begin{array}{c}0.66 \\
7\end{array}$ & $\begin{array}{c}0.01 \\
6\end{array}$ \\
\hline 5 & 0 & NA & NA & NA & NA & $\begin{array}{c}0.63 \\
7\end{array}$ & $\begin{array}{c}0.19 \\
4\end{array}$ & NA & NA & $\begin{array}{c}0.16 \\
5\end{array}$ & $\begin{array}{l}0 . \\
1 \\
2 \\
\end{array}$ & 6 & -74.086 & $\begin{array}{c}161 . \\
31\end{array}$ & $\begin{array}{c}0.75 \\
2\end{array}$ & $\begin{array}{c}0.01 \\
6\end{array}$ \\
\hline 6 & $\begin{array}{c}0.36 \\
5\end{array}$ & NA & NA & NA & + & $\begin{array}{c}0.63 \\
6\end{array}$ & NA & NA & $\begin{array}{c}0.15 \\
5\end{array}$ & $\begin{array}{c}0.20 \\
3\end{array}$ & $\begin{array}{l}\mathrm{N} \\
\mathrm{A}\end{array}$ & 7 & -72.908 & $\begin{array}{c}161 . \\
35\end{array}$ & $\begin{array}{c}0.79 \\
6\end{array}$ & $\begin{array}{c}0.01 \\
5\end{array}$ \\
\hline 7 & 0 & NA & NA & NA & NA & $\begin{array}{c}0.77 \\
3\end{array}$ & NA & NA & NA & NA & $\begin{array}{l}\mathrm{N} \\
\mathrm{A}\end{array}$ & 3 & -77.539 & $\begin{array}{c}161 . \\
39\end{array}$ & $\begin{array}{c}0.83 \\
6\end{array}$ & $\begin{array}{c}0.01 \\
5\end{array}$ \\
\hline 8 & 0 & NA & NA & NA & NA & $\begin{array}{c}0.66 \\
3\end{array}$ & $\begin{array}{c}0.14 \\
7\end{array}$ & NA & NA & NA & $\begin{array}{l}\mathrm{N} \\
\mathrm{A}\end{array}$ & 4 & -76.584 & $\begin{array}{c}161 . \\
69\end{array}$ & 1.14 & $\begin{array}{c}0.01 \\
3\end{array}$ \\
\hline 9 & -0.34 & NA & NA & NA & + & $\begin{array}{c}0.64 \\
2\end{array}$ & NA & NA & NA & $\begin{array}{c}0.13 \\
7\end{array}$ & $\begin{array}{l}0 . \\
1\end{array}$ & 7 & -73.114 & $\begin{array}{c}161 . \\
76\end{array}$ & $\begin{array}{c}1.20 \\
8\end{array}$ & $\begin{array}{c}0.01 \\
2\end{array}$ \\
\hline 10 & $\begin{array}{c}0.31 \\
2\end{array}$ & NA & NA & NA & + & $\begin{array}{c}0.57 \\
9\end{array}$ & $\begin{array}{c}0.10 \\
4\end{array}$ & NA & NA & NA & $\begin{array}{l}\mathrm{N} \\
\mathrm{A}\end{array}$ & 6 & -74.418 & $\begin{array}{c}161 . \\
97\end{array}$ & $\begin{array}{c}1.41 \\
7\end{array}$ & $\begin{array}{c}0.01 \\
1\end{array}$ \\
\hline 11 & 0 & NA & NA & NA & NA & $\begin{array}{c}0.75 \\
9\end{array}$ & NA & NA & NA & $\begin{array}{c}0.12 \\
2\end{array}$ & $\begin{array}{l}0 . \\
1 \\
3\end{array}$ & 5 & -75.631 & $\begin{array}{c}162 . \\
06\end{array}$ & $\begin{array}{c}1.50 \\
8\end{array}$ & $\begin{array}{c}0.01 \\
1\end{array}$ \\
\hline 12 & 0 & NA & NA & NA & NA & 0.73 & NA & NA & NA & NA & $\begin{array}{l}0 . \\
0 \\
9\end{array}$ & 4 & -76.84 & $\begin{array}{c}162 . \\
21\end{array}$ & $\begin{array}{c}1.65 \\
3\end{array}$ & 0.01 \\
\hline 13 & $\begin{array}{c}0.34 \\
4\end{array}$ & 0.054 & NA & NA & + & $\begin{array}{c}0.63 \\
3\end{array}$ & NA & NA & NA & NA & $\begin{array}{l}\mathrm{N} \\
\mathrm{A}\end{array}$ & 6 & -74.583 & $\begin{array}{c}162 . \\
3\end{array}$ & $\begin{array}{c}1.74 \\
7\end{array}$ & 0.01 \\
\hline 14 & $\begin{array}{c}0.32 \\
7\end{array}$ & NA & NA & NA & + & $\begin{array}{c}0.62 \\
1 \\
\end{array}$ & NA & NA & NA & NA & $\begin{array}{l}0 . \\
0 \\
6\end{array}$ & 6 & -74.608 & $\begin{array}{c}162 . \\
35\end{array}$ & $\begin{array}{c}1.79 \\
7\end{array}$ & $\begin{array}{c}0.00 \\
9\end{array}$ \\
\hline 15 & 0 & NA & NA & NA & NA & $\begin{array}{c}0.80 \\
6\end{array}$ & NA & NA & NA & $\begin{array}{c}0.08 \\
5\end{array}$ & $\begin{array}{l}\mathrm{N} \\
\mathrm{A}\end{array}$ & 4 & -76.913 & $\begin{array}{c}162 . \\
35\end{array}$ & $\begin{array}{c}1.79 \\
9\end{array}$ & $\begin{array}{c}0.00 \\
9\end{array}$ \\
\hline 16 & $\begin{array}{c}0.29 \\
7\end{array}$ & NA & NA & NA & + & $\begin{array}{c}0.56 \\
5\end{array}$ & 0.15 & NA & NA & $\begin{array}{c}0.16 \\
4\end{array}$ & $\begin{array}{l}0 . \\
0 \\
9\end{array}$ & 8 & -72.208 & $\begin{array}{c}162 . \\
42\end{array}$ & $\begin{array}{c}1.86 \\
3\end{array}$ & $\begin{array}{c}0.00 \\
9\end{array}$ \\
\hline 17 & $\begin{array}{c}0.35 \\
5\end{array}$ & NA & NA & NA & + & $\begin{array}{c}0.63 \\
3\end{array}$ & NA & $\begin{array}{c}0.09 \\
5\end{array}$ & NA & $\begin{array}{c}0.14 \\
5\end{array}$ & $\begin{array}{l}\mathrm{N} \\
\mathrm{A}\end{array}$ & 7 & -73.506 & $\begin{array}{c}162 . \\
55\end{array}$ & $\begin{array}{c}1.99 \\
3\end{array}$ & $\begin{array}{c}0.00 \\
8\end{array}$ \\
\hline 18 & $\begin{array}{c}0.33 \\
7\end{array}$ & NA & NA & NA & + & $\begin{array}{c}0.61 \\
6\end{array}$ & NA & NA & $\begin{array}{c}0.13 \\
9\end{array}$ & $\begin{array}{c}0.22 \\
1\end{array}$ & $\begin{array}{l}0 . \\
0 \\
9\end{array}$ & 8 & -72.298 & $\begin{array}{c}162 . \\
6\end{array}$ & $\begin{array}{c}2.04 \\
2\end{array}$ & $\begin{array}{c}0.00 \\
8\end{array}$ \\
\hline 19 & 0 & NA & NA & NA & NA & $\begin{array}{c}0.66 \\
4\end{array}$ & $\begin{array}{c}0.17 \\
9\end{array}$ & NA & 0.1 & $\begin{array}{c}0.19 \\
4\end{array}$ & $\begin{array}{l}\mathrm{N} \\
\mathrm{A}\end{array}$ & 6 & -74.743 & $\begin{array}{c}162 . \\
62\end{array}$ & $\begin{array}{c}2.06 \\
6\end{array}$ & $\begin{array}{c}0.00 \\
8\end{array}$ \\
\hline 20 & 0 & NA & NA & NA & NA & $\begin{array}{c}0.76 \\
8 \\
\end{array}$ & NA & $\mathrm{NA}$ & $\begin{array}{c}0.15 \\
8\end{array}$ & $\begin{array}{c}0.18 \\
9\end{array}$ & $\begin{array}{l}\mathrm{N} \\
\mathrm{A}\end{array}$ & 5 & -75.914 & $\begin{array}{c}162 . \\
63 \\
\end{array}$ & $\begin{array}{c}2.07 \\
5\end{array}$ & $\begin{array}{c}0.00 \\
8\end{array}$ \\
\hline 21 & $\begin{array}{c}0.32 \\
8\end{array}$ & NA & NA & NA & + & $\begin{array}{c}0.57 \\
7\end{array}$ & $\begin{array}{c}0.12 \\
6\end{array}$ & NA & $\begin{array}{c}0.11 \\
6\end{array}$ & $\begin{array}{c}0.20 \\
5\end{array}$ & $\begin{array}{l}\mathrm{N} \\
\mathrm{A}\end{array}$ & 8 & -72.321 & $\begin{array}{c}162 . \\
64\end{array}$ & $\begin{array}{c}2.08 \\
9\end{array}$ & $\begin{array}{c}0.00 \\
8\end{array}$ \\
\hline 22 & 0 & NA & NA & $\begin{array}{c}0.0 \\
6\end{array}$ & NA & $\begin{array}{c}0.66 \\
5\end{array}$ & $\begin{array}{c}0.21 \\
3\end{array}$ & NA & NA & $\begin{array}{c}0.15 \\
2\end{array}$ & $\begin{array}{l}\mathrm{N} \\
\mathrm{A}\end{array}$ & 6 & -74.754 & $\begin{array}{c}162 . \\
64\end{array}$ & 2.09 & $\begin{array}{c}0.00 \\
8\end{array}$ \\
\hline 23 & 0 & NA & NA & NA & NA & $\begin{array}{c}0.72 \\
9\end{array}$ & NA & NA & $\begin{array}{c}0.14 \\
3\end{array}$ & $\begin{array}{c}0.21 \\
4\end{array}$ & $\begin{array}{l}0 . \\
1 \\
2\end{array}$ & 6 & -74.793 & $\begin{array}{c}162 . \\
72\end{array}$ & $\begin{array}{c}2.16 \\
6\end{array}$ & $\begin{array}{c}0.00 \\
8\end{array}$ \\
\hline 24 & $\begin{array}{c}0.35 \\
1\end{array}$ & NA & $\begin{array}{c}0.02 \\
1\end{array}$ & NA & + & 0.64 & NA & NA & NA & NA & $\begin{array}{l}\mathrm{N} \\
\mathrm{A}\end{array}$ & 6 & -74.832 & $\begin{array}{c}162 . \\
8\end{array}$ & $\begin{array}{c}2.24 \\
5\end{array}$ & $\begin{array}{c}0.00 \\
7\end{array}$ \\
\hline 25 & 0 & 0.063 & NA & NA & NA & $\begin{array}{c}0.76 \\
5\end{array}$ & NA & NA & NA & NA & $\begin{array}{l}\mathrm{N} \\
\mathrm{A}\end{array}$ & 4 & -77.146 & $\begin{array}{c}162 . \\
82\end{array}$ & $\begin{array}{c}2.26 \\
4\end{array}$ & $\begin{array}{c}0.00 \\
7\end{array}$ \\
\hline 26 & $\begin{array}{c}0.34 \\
5\end{array}$ & NA & NA & $\begin{array}{l}0.0 \\
08 \\
\end{array}$ & + & $\begin{array}{c}0.64 \\
2\end{array}$ & NA & NA & NA & NA & $\begin{array}{l}\mathrm{N} \\
\mathrm{A}\end{array}$ & 6 & -74.871 & $\begin{array}{c}162 . \\
88\end{array}$ & $\begin{array}{c}2.32 \\
3\end{array}$ & $\begin{array}{c}0.00 \\
7\end{array}$ \\
\hline 27 & $\begin{array}{c}0.34 \\
8\end{array}$ & NA & NA & NA & + & $\begin{array}{c}0.63 \\
8\end{array}$ & NA & NA & $\begin{array}{c}0.00 \\
6\end{array}$ & NA & $\begin{array}{l}\mathrm{N} \\
\mathrm{A}\end{array}$ & 6 & -74.874 & $\begin{array}{c}162 . \\
88\end{array}$ & $\begin{array}{c}2.32 \\
9\end{array}$ & $\begin{array}{c}0.00 \\
7\end{array}$ \\
\hline 28 & $\begin{array}{c}0.34 \\
7\end{array}$ & NA & NA & NA & + & $\begin{array}{c}0.63 \\
8\end{array}$ & NA & $\begin{array}{c}0.00 \\
5\end{array}$ & NA & NA & $\begin{array}{l}\mathrm{N} \\
\mathrm{A}\end{array}$ & 6 & -74.875 & $\begin{array}{c}162 . \\
89\end{array}$ & $\begin{array}{c}2.33 \\
2\end{array}$ & $\begin{array}{c}0.00 \\
7\end{array}$ \\
\hline 29 & 0 & NA & $\begin{array}{c}0.06 \\
8\end{array}$ & NA & NA & $\begin{array}{c}0.62 \\
5\end{array}$ & $\begin{array}{c}0.18 \\
3\end{array}$ & NA & NA & $\begin{array}{c}0.16 \\
9\end{array}$ & $\begin{array}{l}0 . \\
1 \\
6\end{array}$ & 7 & -73.721 & $\begin{array}{c}162 . \\
98\end{array}$ & $\begin{array}{c}2.42 \\
2\end{array}$ & $\begin{array}{c}0.00 \\
7\end{array}$ \\
\hline 30 & $\begin{array}{c}0.36 \\
8\end{array}$ & 0.039 & NA & NA & + & $\begin{array}{c}0.66 \\
1\end{array}$ & NA & NA & NA & $\begin{array}{c}0.09 \\
8\end{array}$ & $\begin{array}{l}\mathrm{N} \\
\mathrm{A}\end{array}$ & 7 & -73.756 & $\begin{array}{c}163 . \\
05\end{array}$ & $\begin{array}{c}2.49 \\
3\end{array}$ & $\begin{array}{c}0.00 \\
7\end{array}$ \\
\hline
\end{tabular}


Table A1.6. Average weighted parameter values for statistical models (mean and $95 \%$ confidence intervals) for models for total subsidy level for 1914-1994.

\begin{tabular}{|l|c|c|c|}
\hline & mean & lower & upper \\
\hline Intercept & -0.024 & -0.161 & 0.113 \\
\hline AR1 & 0.753 & 0.517 & 0.988 \\
\hline AR2 & -0.02 & -0.173 & 0.133 \\
\hline AR3 & -0.026 & -0.179 & 0.127 \\
\hline AR4 & -0.001 & -0.146 & 0.144 \\
\hline AR5 & 0.081 & -0.117 & 0.278 \\
\hline Yr & 0.147 & -0.076 & 0.371 \\
\hline Oil & 0.029 & -0.089 & 0.146 \\
\hline dManufact & -0.006 & -0.054 & 0.041 \\
\hline polright & 0.068 & -0.184 & 0.32 \\
\hline polsocial & 0.02 & -0.114 & 0.153 \\
\hline Landval & 0.013 & -0.056 & 0.082 \\
\hline
\end{tabular}

Table A1.7. Average weighted parameter values for statistical models (mean and $95 \%$ confidence intervals) for models for subsidy color (fraction beneficial to capacity enhancing subsidies) for 1914-1994.

\begin{tabular}{|l|r|r|r|}
\hline & mean & \multicolumn{1}{|c|}{ lower } & \multicolumn{1}{c|}{ upper } \\
\hline Intercept & -0.161 & -0.58 & 0.257 \\
\hline polright & 0.227 & -0.377 & 0.831 \\
\hline polsocial & 0.215 & -0.31 & 0.739 \\
\hline AR1 & 0.659 & 0.424 & 0.894 \\
\hline AR2 & 0.064 & -0.156 & 0.284 \\
\hline AR3 & 0.007 & -0.12 & 0.134 \\
\hline AR4 & 0.026 & -0.138 & 0.189 \\
\hline AR5 & -0.095 & -0.315 & 0.125 \\
\hline Landval & -0.01 & -0.102 & 0.081 \\
\hline dManufact & 0.014 & -0.079 & 0.106 \\
\hline Yr & 0.045 & -0.118 & 0.209 \\
\hline Oil & 0.006 & -0.08 & 0.092 \\
\hline
\end{tabular}



Fig A1.1. Percent fishers in the Swedish population. Note that the fishing has never been a major Swedish industry (the fisher population never exceeded $0.15 \%$ ) but has decreased further since the 1960s. In 2014, the Swedish population was 9.7 million and the number of fishers were 1100, which yields the fraction fisher of the total population $0.01 \%$. 
A

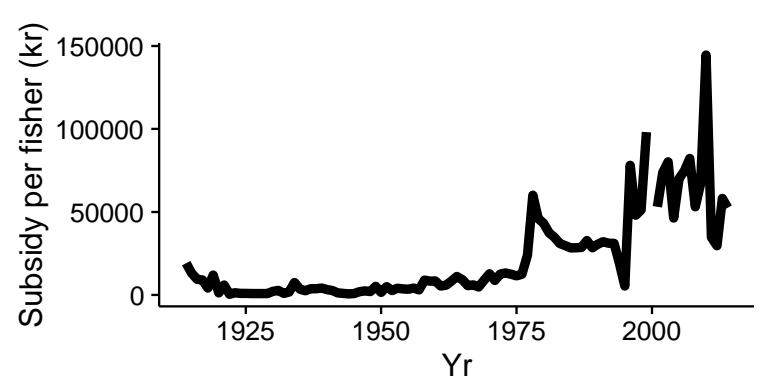

B



Fig A1.2. Time series of subsidy levels (all three categories): (A) per fisher, and (B) per total gross landing value. Note that both subsidy per fisher and subsidy in relation to landing value has increased strongly over time.

\section{Supplementary References}

Bristol, N., 2009. Obama allocates funds for health-care priorities. Lancet 373, 881-882.

Furman, J., 2006. Two wrongs do not make a right. Natl. Tax J. 59, 491-508.

Moehlmann, J., 1992. Initiative on biotechnology research in Bush budget proposal.

Bioscience 42, 455.

SOU, 1992. Statens Offentliga Utredningar 1992:136. Svenskt fiske. Nuläge och utvecklingsmöjligheter.

Sumaila, U., Khan, A.S., Dyck, A.J., Watson, R., Munro, G., Tyedmers, P., Pauly, D., 2010. A bottom-up re-estimation of global fisheries subsidies. J. Bioeconomics 201-225. doi:10.1007/s10818-010-9091-8 